\title{
Oxidative stress-induced telomeric erosion as a mechanism underlying airborne particulate matter-related cardiovascular disease
}

Thomas J Grahame ${ }^{* *}$ and Richard B Schlesinger ${ }^{2}$

\begin{abstract}
Particulate matter (PM) pollution is responsible for hundreds of thousands of deaths worldwide, the majority due to cardiovascular disease (CVD). While many potential pathophysiological mechanisms have been proposed, there is not yet a consensus as to which are most important in causing pollution-related morbidity/mortality. Nor is there consensus regarding which specific types of PM are most likely to affect public health in this regard. One toxicological mechanism linking exposure to airborne PM with CVD outcomes is oxidative stress, a contributor to the development of CVD risk factors including atherosclerosis. Recent work suggests that accelerated shortening of telomeres and, thus, early senescence of cells may be an important pathway by which oxidative stress may accelerate biological aging and the resultant development of age-related morbidity. This pathway may explain a significant proportion of PM-related adverse health outcomes, since shortened telomeres accelerate the progression of many diseases. There is limited but consistent evidence that vehicular emissions produce oxidative stress in humans. Given that oxidative stress is associated with accelerated erosion of telomeres, and that shortened telomeres are linked with acceleration of biological ageing and greater incidence of various age-related pathology, including CVD, it is hypothesized that associations noted between certain pollution types and sources and oxidative stress may reflect a mechanism by which these pollutants result in CVD-related morbidity and mortality, namely accelerated aging via enhanced erosion of telomeres. This paper reviews the literature providing links among oxidative stress, accelerated erosion of telomeres, CVD, and specific sources and types of air pollutants. If certain PM species/sources might be responsible for adverse health outcomes via the proposed mechanism, perhaps the pathway to reducing mortality/morbidity from PM would become clearer. Not only would pollution reduction imperatives be more focused, but interventions which could reduce oxidative stress would become all the more important.
\end{abstract}

Keywords: Telomere, Oxidative stress, Particulate matter, Cardiovascular disease, Black carbon, Vehicular emissions

\section{Introduction}

Epidemiological studies have found associations between exposure to airborne particulate matter (PM) and adverse effects on the cardiovascular system, as well as increased incidence or prevalence of cardiovascular disease (CVD)-related morbidity and mortality [1,2]. However, the pathophysiology underlying this relationship has not been clearly defined. One mechanism underlying PM-related CVD is oxidative stress. This occurs when

\footnotetext{
* Correspondence: thomas.grahame@hq.doe.gov

${ }^{1}$ United States Department of Energy, 1000 Independence Avenue, SW Washington, DC 20585, USA

Full list of author information is available at the end of the article
}

the homeostatic balance of oxidizing agents to antioxidants is upset towards an imbalance of the former. The primary oxidizing agents in this regard are reactive oxygen species (ROS), such as hydroxyl radical and superoxide anion. While these are normal products of aerobic metabolism, under conditions whereby ROS production increases beyond the ability to detoxify these chemicals, molecular damage may result since ROS readily reacts with proteins, lipids and nucleic acids.

An American Heart Association Scientific Statement on Particulate Matter has proposed a role for oxidative stress in altering cardiac function [2]. A review of the relationship between oxidative stress and air pollutants

\section{Biomed Central}


discussed the role of fine PM, and certain more biologically active components thereof, in causing both primary oxidizing effects in lung lining fluid and a secondary wave of oxidative stress via influx of inflammatory cells [3]. A recent report from the Health Effects Institute hypothesized that oxidative stress might indeed be the underlying mechanism of action by which exposure to pollutants specifically from traffic may lead to adverse health outcomes [4]. Furthermore, a review of in vitro, in vivo and epidemiological studies examining vehicularderived PM emissions and their association with cardiovascular morbidity and mortality concluded that one of the major toxicological mechanisms likely linked to CVD is oxidative stress [5]. Finally, there is increasing evidence that some specific components of airborne PM that may contribute little to total $\mathrm{PM}_{2.5}$ mass may be responsible for inducing oxidative stress [6].

Advanced age is a known risk factor for a number of chronic diseases and functional impairment, including those involving the cardiovascular system. However, as opposed solely to chronological age, "biological" age, which is determined both by physiology as well as chronology, appears to be a key factor related to development of ultimate pathology and this, in turn, has been related to a cumulative burden of oxidative stress [7]. There is also increasing evidence that biological aging is related to shortening of chromosomal telomeres.

Telomeres are structures consisting of noncoding nucleotide sequences (telomeric DNA), associated with certain proteins, found at both ends of chromosomal DNA molecules. They help protect against erosion of coding DNA, which would lead to subsequent loss of genetic information on the chromosomes during repetitive replication cycles.

Several proteins associated with telomeric DNA, including telomerase, a reverse transcriptase enzyme, and the telomeric repeat binding factors 1 and 2 (TRF1, TRF2), help regulate telomere length and structure. Telomerase is involved in the replication of telomeric DNA strands, so as to preserve their length when chromosomal DNA is replicated. However, in most mammalian somatic cells, as opposed to germ and stem cell lines, activity of telomerase is very low, or even absent $[8,9]$, resulting in incomplete replication of the telomere and the loss of a certain number of telomeric DNA base pairs during each division cycle with subsequent shortening of the telomere itself. Because progressive shortening of telomeres is a crucial factor in the normal process of organismal aging, telomeric length can serve as a marker of a cell's biological age, in contrast to actual chronological age [10,11].

The natural erosion of telomeric length is cumulative. Eventually, with repetitive cell divisions, the telomere reaches a critical length, and further cell division can no longer proceed. The cell then becomes senescent, and eventually undergoes apoptosis. Senescent cells have been reported to accumulate in tissues and organs, with potential to interfere with normal tissue function and structure. Senescence has also been causally related to the generation of age-related phenotypes, since removal of senescent cells seems to prevent or delay tissue dysfunction [12].

It is of interest to note that significant telomerase activity has been found in approximately $90 \%$ of human cancers, regardless of cell type $[13,14]$, in contrast to normal somatic cells as previously noted. The abnormally increased levels of telomerase allow these cells to continue to divide rather than become senescent with repeated DNA replication cycles [9]. However, when telomerase activity in these cells was inhibited, telomeres became shorter with each division, and eventually cell growth ceased.

The rate of telomeric erosion over time is determined partially by genetic factors and partially by environmental factors, and their interaction likely modulates biological aging, affecting the risk of developing age-related diseases [15]. A role for biological age "advancement" in heart failure and the pathogenesis of myocardial infarction (MI) has been suggested [16], and shortened telomeres appear to be responsible for accelerating several important CVD disease states and risk factors, including hypertension and atherosclerosis [17].

This paper reviews the relationship between telomeric length, CVD, and oxidative stress, and discusses a role for specific PM air pollutants and pollutant sources in inducing oxidative stress. Based upon the available evidence, we propose that a potential mechanism underlying at least some PM exposure association with CVD involves an accelerated rate of cell telomere erosion due to oxidative stress, resulting in an acceleration of the rate of biological aging. This may be an important and generalized mechanism underlying PM-related increases in CVD morbidity and mortality.

\section{Linking oxidative stress and telomere length}

The ability of oxidative stress to damage DNA provides a potential mechanism by which it could interfere with replication of telomeric DNA, accelerating the rate of telomeric erosion. A study examining the effect on circulating leukocyte telomeric length in people in relation to status of the UCP2 gene, which is involved in the regulation of mitochondrial ROS production, found that the presence of a functional promoter UCP2 variant that resulted in increased oxidative stress via down regulation of gene expression was associated with shorter telomeric length than when the variant was absent, suggesting a direct link between ROS and accelerated telomeric erosion [18]. Telomere DNA is very prone to such oxidative 
damage since it is especially rich in guanine; accumulation of this damage along the telomere during the lifespan of a cell can then result in enhanced telomere loss during each replication cycle, thus contributing to accelerated cell senescence $[19,20]$.

Reactive oxygen species can damage DNA either directly or during attempted repair of oxidation-induced base modifications [20]. In addition, as already noted, telomeric DNA is inefficient in repair of single strand breaks or other induced lesions, in contrast to most genomic DNA, in that repair is either slower or more incomplete [21]. This inefficiency may be further enhanced by oxidative damage to any telomerase which may be present in the cell. For example, increased levels of intracellular ROS have been shown to result in a reduction of telomerase activity, which can be prevented by the presence of ROS scavengers which also delay the onset of cellular senescence [22]. Thus, due to the sensitivity of both telomerase and telomeric DNA to oxidative-induced damage and the normal insufficiency of repair mechanisms, telomeres are especially sensitive to cumulative oxidative damage [23]. Therefore, oxidative stress is a likely environmental factor accelerating telomeric erosion at each replication cycle, with resultant accelerated cellular biological aging [24].

The extent of telomeric erosion has been related to the level of oxidative stress. Richter and van Zglinicki [25] examined the rate of telomeric shortening under conditions of oxidative stress induced by varying levels of oxygen in cultures of fibroblasts obtained from human adult skin, foreskin, embryonic lung and sheep embryos. The investigators reported a correlation between ROS levels and the rate of telomeric shortening, which was independent of the individual human donor or specific animal species. They further suggested that a given level of intracellular ROS would lead to a predictable acceleration of the rate of shortening of telomeres over the norm, regardless of any other difference between donors in terms of individual genetics within one species, or between species. Furthermore, high levels of intracellular ROS and accumulated damage to DNA and protein have been associated with the development of senescent somatic cells, compared with much less oxidative damage noted in more "immortal" cell types that can continue to divide for longer periods of time [26,27].

If oxidative stress plays a role in telomeric erosion, then the presence of antioxidants should result in some modulation of this effect. Overexpression of extracellular superoxide dismutase resulted in a decrease in both the peroxide content of human fibroblasts, and the rate of telomeric shortening [28]. An association between oxidative stress and increased rate of telomeric shortening, likely due to direct ROS-induced damage to telomeric DNA, and the preventative role of antioxidants in decelerating this rate, has been shown in a number of other in vitro studies as well $[19,21,29,30]$.

The role of oxidative stress as an environmental factor modulating telomeric length has also been suggested by epidemiological studies. Most of these involved assessment of CVD, and are discussed in subsequent sections. Acceleration of the appearance of age-related pathology is supported by a study that found leukocyte telomere length associated with age-related disease burdens across multiple physiological systems, and that was independent of its association with actual chronological age [31]. This provided direct evidence that mechanisms which shorten telomere length, such as oxidative stress, will likely cause progression of a variety of diseases, including CVD.

\section{Linking CVD and telomere length}

A number of epidemiological studies involving diverse populations have consistently show an association between shorter telomeric length in cells obtained from patients with CVD compared to healthy people. One such study examined the relationship between telomeric length in circulating leukocytes and various indices or risk factors for clinical CVD in a group of 419 adults aged over 65 yrs (mean age 74.2 yr) [32]. It noted a statistically significant to borderline significant inverse relationship between telomere length and C-reactive protein, IL-6, carotid artery intima media thickness, and ankle brachial index, but only in those aged 73 yrs or younger. It appears that the effect of shorter telomere length on disease outcome attenuates above a certain chronological age. In another study, leukocyte mean telomere length was examined in a group of people having mean age of $78 \mathrm{yr}$, and then in surviving members of this group seven years later and having mean age of 83 yr [33]; shorter length was predictive of CVD-related mortality only for men under 80 yrs of age. On the other hand, some studies have found no association between telomere length and carotid artery media thickness $[34,35]$. The reasons for the apparent inconsistency are unclear, but may be a function of the specific populations examined in this regard.

Another study compared leukocyte telomere length in a population of 484 men (age 45-65 yr) who subsequently developed coronary heart disease with that from 1058 matched controls who did not have any CVD events [36]. Those in the mid and lowest tertiles of telomeric length at the time of recruitment into the study had approximately a two fold greater risk of developing some form of coronary heart disease over the next $4.9 \mathrm{yr}$ than did those in the highest tertile. This study, similar to the study noted above [33], strongly suggested that mean leukocyte telomere length was a predictor of future CVD, and that the relationship between telomeric 
length and CVD was not a consequence of the disease but, rather, a factor in its development.

Similarly, a study of 143 people over the age of $60 \mathrm{yrs}$ found that the presence of shorter than population average telomere length was associated with a greater than threefold increase in cardiac mortality over approximately the following 9 years [37]. An association of reduced telomere length with increased risk of myocardial infarction (MI) and other cardiac diseases, and with greater mortality rate, has also been found [38]; the risk of MI, considered as premature MI, in people under age 50 was higher for those with shorter telomere lengths compared to those with lengths in the highest quartile. Attrition of telomere length has also been noted in people showing age-related cardiomyopathy [39]. Telomere shortening has also been linked to CVD via impairment of cardiac stem cell-mediated myocardial regeneration, and may also contribute to CVD by inducing myocardial cell apoptosis apart from any effect on stem cells $[40,41]$.

A potential familial predisposition to CVD, perhaps related to telomeric length, was described by Wong et al. [42]. They measured leukocyte telomeric length in patients having ischemic heart failure and in their high risk children, and noted that length was shorter in cells from patients and their children compared to healthy controls and their children. A study using biopsy material [39] found that myocytes from hearts of diseased elderly people showed a $39 \%$ reduction in average telomeric length, and a higher degree of necrosis and apoptosis, than did comparable cells from healthy controls. Another study [41] noted that telomeric length in leukocytes of people with dilated, failing hearts, compared with those from aged-matched healthy controls, had lengths that were $25 \%$ shorter, decreased expression of TRF-2, and marked activation of a kinase involved in DNA repair.

Most studies of telomere length in vivo used circulating leukocytes as they are easy to obtain. Kuznetsova et al. [43] addressed the issue of whether telomeric length in circulating leukocytes was representative of that in the cardiac myocytes themselves. It appears that the rate of telomeric shortening is indeed similar in different tissues of any individual and, therefore, easily accessible cells such as circulating leukocytes can indeed serve as surrogates for telomere length assessment in those cells involved in specific disease processes, such as vessel endothelium or cardiac myocytes $[20,44,45]$.

Since shortening of telomeric length is associated with cell senescence and biological age, and with diseases normally associated with increasing chronological age, one of the ways in which differences in telomeric length in people with or without CVD may be expressed is by the number of years of chronological age to which this difference in length can be equated [7]. In most subjects under the age of $70 \mathrm{yrs}$, there seems to be a consistent chronological to biological age difference equivalent of between 8 and 12 yrs [36,38]. In other words, those people who will go on to develop or already have CVD show telomeres with average lengths equivalent to healthy people who are chronologically 8 to $12 \mathrm{yrs}$ older.

Specific risk factors for CVD or specific CVD-related conditions have also been examined in relation to telomere length. Telomere length in leukocytes was found to be related to altered left ventricular mass, a determinant of cardiac function, both longitudinally and crosssectionally, in a study involving 334 people with mean age of $46.5 \mathrm{yr}$ [43]. Shorter mean telomere length in leukocytes has also been reported to be associated with a decreased left ventricular ejection fraction in the elderly who had no prior evidence of cardiac disease [46]. Chronic heart failure, a condition in which the heart has lost the ability to pump enough blood to the body's tissues, is often the result of valvular heart disease, such as aortic valve stenosis, that results in ventricular hypertrophy and resulting compromised cardiac function. Decreased leukocyte telomere length has been found to be associated with degenerative aortic stenosis [47].

Increased cardiomyocyte apoptosis is a characteristic of chronic heart failure $[41,48]$. Telomerase knockout mice, in which telomeres show increased rate of shortening, have attenuated myocyte division, increased rate of apoptosis, and cardiomyocyte hypertrophy, all leading to cardiac remodeling that mimics human endstage dilated cardiomyopathy [49]. This suggests that telomeres may play a primary role in CVD through their impact on cellular senescence, and that shorter telomere length associated with CVD may not be merely a reflection of the greater extent of vascular cell turnover that occurs in these conditions [7]. On the other hand, the increased cell turnover noted could result in even further enhanced telomere attrition than would occur normally [50]. Telomerase activity has also been found to be significantly reduced in patients (median age $80-82$ yr) with congestive heart failure compared to healthy controls [51].

The extent of coronary atherosclerosis, indicated by the occurrence and relative extent of coronary artery calcification, may be a predictor of a coronary event and an index of the biological age of the artery [52-55]. A crosssectional study examined the relationship between telomere length and calcification in a group of 325 adults (aged 40-64 yr) [56]. An inverse relationship was noted between telomere length and coronary arterial calcification in people with no clinical history of cardiac disease. Shorter mean telomere length in leukocytes has also been reported to be associated with an increased 
tendency of carotid artery atherosclerosis in hypertensive individuals [57].

The relationship between arterial tissue and telomere length was examined in 84 subjects (mean age $69 \mathrm{yr}$ ). Telomere length was shorter in aortic tissue which showed atherosclerosis than did corresponding tissue without these lesions [58]. Another study [59] examined telomere length in leukocytes and atherosclerotic plaques from patients with carotid atherosclerosis and in blood cells of age and gender-matched controls who had no clinical evidence of atherosclerosis. Telomere length was shorter in patients than in controls, although length in the plaque cells was only weakly correlated with that in the white cells.

Linking CVD, oxidative stress and telomere length The discussion in the previous sections provided evidence that telomere length is modulated by oxidative stress, and that shortened telomere length may be a factor in the pathogenesis of CVD. This section integrates these concepts, discussing the relationship between oxidative stress, telomere length, and overt CVD or risk factors.

A known risk factor for CVD is chronic psychological stress $[60,61]$, the proposed mechanism for which is psychological stress-induced oxidative stress due to autonomic nervous system and neuroendocrine responses [11]. For example, adrenal glucocorticoid hormones have been shown to increase oxidative stress-related neuronal damage $[62,63]$.

Epel et al. [11] studied leukocyte telomere length in a group of 50 women, 20-50 yrs of age (mean $38 \mathrm{yr}$ ), who were undergoing chronic or perceived life stress but were otherwise healthy. They found both perceived and chronic stress to be positively correlated with oxidative stress, using F2-isoprostane in urine, a biomarker of lipid peroxidation. They postulated that psychological stress can induce early cell senescence leading to CVD. In another study, leukocyte telomere length was examined in a small group of people with chronic depression [64]. Various markers of oxidative stress were assessed; telomere length was inversely correlated with the level of oxidative stress in all subjects.

As noted above, telomere length can reflect biological aging and the risk of CVD. Telomere length in endothelial progenitor cells from patients with CVD was found to be shorter, and telomerase activity lower, than in healthy matched controls; oxidative stress in the ill subjects was also greater [65]. In a longitudinal study involving a cohort of 2059 people aged 35-55 yr (average 46 yrs) who were free of any overt CVD [50], baseline leukocyte telomere length showed no significant correlation with single measures of cholesterol HDL level and blood pressure, known CVD risk factors, but shorter length was significantly associated with increased levels of several markers of oxidative stress. This study suggested that telomere length reflected the burden of oxidative stress seemingly independent of life style, as indicated by these other classical risk factors. However, the rate of leukocyte telomere shortening has been associated with longitudinal "cumulative" levels of cholesterol HDL [66] suggesting, as noted above, that telomere length may be reflective of an accumulating lifetime burden of oxidative stress, and that more "instant" markers of risk taken at any one time may not be as reflective and, therefore, may show no clear association with length.

There is other evidence for the relation between CVD and oxidative stress. For example, lipid peroxidation induced by ROS is an early event in the atherosclerotic process [67]. Hydrogen peroxide and oxidized low density lipoproteins have been found to inhibit endothelial cell telomerase activity [68]. Furthermore, long-term exposure of human vascular endothelial cells to oxidative stress induced by alteration of the glutathione redox cycle resulted in down-regulation of telomerase activity, enhanced erosion of telomeres, and early onset of cellular senescence [69].

Diabetes, another risk factor for CVD, is associated with high levels of oxidative stress resulting in cellular damage and accelerated cellular aging [16]. Impairment in the function of cardiac progenitor cells involved in regeneration of damage in the cardiovascular system resulting from diabetes-enhanced oxidative stress is one of the likely underlying causes of diabetic cardiomyopathy. Type 2 diabetes has also been associated with shorter telomeric length in white blood cells, and diabetes appears to accelerate telomeric shortening in these cells in patients having a history of MI.

In sum, the available evidence supports a role for oxidative stress in accelerating telomere shortening, inasmuch as diseases in which chronic oxidative stress is a hallmark are associated with shortened length. This, in turn, provides support for an association between accelerated rate of telomere erosion due to oxidative stress and CVD pathophysiology. Furthermore, differences in telomere length in individuals with or without CVD cannot be consistently explained merely by differences in some classical risk factors for CVD other than age, such as obesity, BMI, smoking status, or cholesterol level $[32,36,38,50,70]$. At best, there is only little to moderate association with shorter lengths and these factors, if any relationship is noted at all, suggesting that oxidative stress is a potentially greater risk factor. Thus, a reduction in the cellular replicative capacity of cardiac or other tissues within the cardiovascular system due to oxidative stress-induced accelerated erosion of telomere length may be directly involved in the progression to CVD, and may even determine its severity [43]. 


\section{Linking exposure to $\mathrm{PM}_{2.5}$ species or sources and telomere length or oxidative stress Linking with telomere length}

There is some, albeit limited, evidence that exposure to traffic-related emissions can modulate telomere length. In a study conducted in Milan, Italy [71], mean telomere length was found to be significantly shorter in traffic officers than in office worker controls, and in traffic officers working in high traffic vs. those working in low traffic areas. Telomere length also decreased with increasing chronological age in both traffic officers and office workers, but was shorter in traffic officers for each age category and was also decreased with increased exposure levels to vehicular emissions (i.e., benzene and toluene).

In a study of 165 veterans in the greater Boston area, McCracken et al. [17] modeled black carbon (BC) concentrations in the homes of subjects, and found that an interquartile increase of $\mathrm{BC}\left(0.25 \mu \mathrm{g} / \mathrm{m}^{3}\right)$ was associated with a significant decrease in telomere length; statins, which have both anti-inflammatory and antioxidant properties, had a protective effect on telomere shortening.

\section{Linking with oxidative stress}

This section reviews human panel studies which link traffic-related emissions to several different measures of oxidative stress. Some studies compared oxidative stress in people exposed to traffic or diesel emissions for several hours or during a workshift, compared to matched controls not so exposed, while others linked levels of specific $\mathrm{PM}_{2.5}$ species with oxidative stress. Because oxidative stress is also associated with telomere shortening, as reviewed in previous sections, these studies would then provide a link to traffic-related emissions generally, or specific components of such emissions.

Studies which involved only measures of total PM mass have not been included herein, because they cannot inform us as to which specific $\mathrm{PM}_{2.5}$ species are associated with health risks. On the other hand, we have emphasized studies which: (A) assessed either at least two specific $\mathrm{PM}_{2.5}$ species or total $\mathrm{PM}_{2.5}$ mass and at least one $\mathrm{PM}_{2.5}$ species including $\mathrm{BC} / \mathrm{EC}$; and (B) have accurate exposure information for those chemical species exhibiting local variability. Regarding (A), it is possible that a significant association for a pollutant variable might exist only because of the lack of measurement of another important $\mathrm{PM}_{2.5}$ species. Regarding (B), recent studies $[72,73]$ have found that accurate subject exposure accounted for the difference between finding small, insignificant health risk associations when a central monitor was used to characterize overall exposure for everyone within a large geographic area and greater, more significant, associations using a more accurate exposure metric, e.g., monitors outside or inside residences, or personal monitors. A summary of relevant human panel studies meeting the criteria noted above is provided in Table 1. Table 2 illustrates the differences in findings in one study [72] when exposure to a specific pollutant, namely black carbon, was assessed using personal monitors compared to when exposure assessment utilized a central monitor.

\section{Studies providing direct measures of oxidative stress}

As noted previously, oxidative stress in this paper has been defined as an imbalance between the generation and removal of free radicals. Air pollution studies have used several direct markers of this oxidative stress response. These include the following:

- circulating biomarkers of erythrocyte antioxidant activity in blood, such as glutathione peroxidase-1 $(\mathrm{GPx}-1)$ and copper-zinc superoxide dismutase $(\mathrm{Cu}$, Zn-SOD).

- 8-hydroxy-2'-deoxyguanosine (designated as either 8-OHdG or 8-oxodG) in urine or in lymphocytes, a product of oxidation of the deoxynucleotide pool, and of oxidation of guanine in DNA.

- increases in redox-sensitive transcription factors.

- differences in oxidative stress-related gene activity among subjects exposed to pollutants.

Delfino et al. $[74,75]$ examined elderly non-smoking retirees having coronary artery disease and living in several centers across the Los Angeles area. Pollution monitors were located both inside and outside residences, and measures of oxidative stress included circulating biomarkers in blood (GPx-1, Cu, Zn-SOD). These are among the few studies that considered secondary organic aerosols (SOA), which in Los Angeles would mainly be oxidation products of carbonaceous gases of vehicular origin, among the different $\mathrm{PM}_{2.5}$ species being considered. The studies found associations for $\mathrm{Cu}, \mathrm{Zn}$ SOD with primary $\mathrm{PM}_{2.5}$ species mainly of vehicular origin $\left(\mathrm{EC}, \mathrm{BC}\right.$, primary organic carbon, $\mathrm{PM}_{0.25}$ ), but not SOA or mixed secondary and primary organic species $(\mathrm{OC})$. Inorganic secondary aerosols, such as sulfate, were not monitored, presumably because major sulfate sources, such as coal-fired power plants, were several hundred miles downwind from the study area.

Loft et al. [77] examined 8-OHdG levels in 57 bus drivers in Copenhagen, 30 who drove urban routes and 27 who drove rural/suburban routes. 8-OHdG excretion was significantly elevated in the former compared to the latter. Although urban atmospheres appeared to be the cause of oxidative stress, this study did not assess specific vehicular-derived emissions.

Wei et al. [79] examined pre- and post-work shift 8OHdG levels in security workers in Beijing, whose work site was on a heavily trafficked road. Four "clusters" of 
Table 1 Human panel studies with good subject exposure methodologies associating measures of oxidative stress with different pm ${ }_{2.5}$ species or

\section{specific sources}

\begin{tabular}{|c|c|c|c|c|c|}
\hline Study & $\begin{array}{l}\text { Oxidative stress } \\
\text { measures }\end{array}$ & Subjects & $\begin{array}{l}P M_{2.5} \text { species, other } \\
\text { measures of exposure }\end{array}$ & Associations found & $\begin{array}{l}\text { Accuracy of subject } \\
\text { exposure to } B C / E C^{1}\end{array}$ \\
\hline Delfino et al., 2008 [74] & $\begin{array}{l}\text { Circulating GPx-1, } \\
\mathrm{Cu}, \mathrm{Zn}-\mathrm{SOD}\end{array}$ & $\begin{array}{l}29 \text { non-smoking elderly } \\
\text { w/CAD in Los Angeles area, } \\
\text { many on statins or } \\
\text { anti-hypertension meds; } \\
12 \text { weekly blood draws }\end{array}$ & $\begin{array}{l}\text { Ambient } \mathrm{PM}_{0.25}, \mathrm{PM}_{2.5}, \mathrm{PN}, \mathrm{EC} \\
\mathrm{OC}, \mathrm{BC}, \mathrm{OC}_{\text {pri, }} \mathrm{SOA}\end{array}$ & $\begin{array}{l}\text { For Cu, Zn-SOD: Associations } \\
\text { found with PM } \mathrm{M}_{0.25}, \mathrm{PM}_{2.5}, \mathrm{EC}, \mathrm{BC} \text {, } \\
\mathrm{OC}_{\text {pri, }} \text { but not with OC, PN, SOA }\end{array}$ & $\begin{array}{l}\text { Very good: monitors inside } \\
\text { and outside retirement } \\
\text { communities }\end{array}$ \\
\hline Delfino et al., 2009 [75] & $\begin{array}{l}\text { Circulating GPx-1, } \\
\mathrm{Cu}, \mathrm{Zn}-\mathrm{SOD}\end{array}$ & $\begin{array}{l}60 \text { non-smoking elderly } \\
\text { w/CAD in Los Angeles area, } \\
\text { many on statins or } \\
\text { anti-hypertension meds; } \\
5-12 \text { weekly blood draws }\end{array}$ & $\begin{array}{l}\text { Ambient } \mathrm{PM}_{0.25}, \mathrm{PM}_{2.5}, \mathrm{PN}, \mathrm{EC} \\
\mathrm{OC}, \mathrm{OC}_{\text {pri, }} \mathrm{SOA}\end{array}$ & $\begin{array}{l}\text { For } \mathrm{Cu}, \mathrm{Zn} \text {-SOD: Associations } \\
\text { (stronger in cool season) with } \\
\mathrm{PM}_{0.25} \mathrm{PM}_{2.5,} \mathrm{EC}, \mathrm{PN}, \mathrm{OC}_{\text {pri, }} \\
\text { but not with OC, SOA }\end{array}$ & $\begin{array}{l}\text { Very good: monitors inside } \\
\text { and outside retirement } \\
\text { communities }\end{array}$ \\
\hline Kim et al., 2004 [76] & $8-\mathrm{OHdG}$ & $\begin{array}{l}20 \text { boilermakers, average } \\
45.5 \text { year of age, repairing } \\
\text { oil-fired boilers in Boston } \\
\text { area }\end{array}$ & $\begin{array}{l}\text { Industrial levels of } \mathrm{PM}_{2.5} \\
\mathrm{PM}_{2.5} \text { metals } \mathrm{V}, \mathrm{Cr}, \mathrm{Mn}, \mathrm{Ni}_{1} \\
\mathrm{Cu}, \mathrm{Pb}\left(\mathrm{PM}_{2.5}=440 \mu \mathrm{g} / \mathrm{m}^{3},\right. \\
\mathrm{V}=1.23 \mu \mathrm{g} / \mathrm{m}^{3}, \text { other } \\
\left.\text { metals }<1.0 \mu \mathrm{gg} / \mathrm{m}^{3}\right)\end{array}$ & $\begin{array}{l}\text { Post work shift 8-OHdG levels } \\
\text { significantly higher than pre } \\
\text { shift; increased } \mathrm{PM}_{2.5}, \mathrm{~V}, \mathrm{Mn} \text {, } \\
\mathrm{Ni} \text {, Pb concentrations significantly } \\
\text { associated with increased 8-OHdG }\end{array}$ & $\begin{array}{l}\text { Excellent: personal } \\
\text { monitors used }\end{array}$ \\
\hline Loft et al., 1999 [77] & 8-oxodG & $\begin{array}{l}57 \text { non-smoking diesel bus } \\
\text { drivers in greater } \\
\text { Copenhagen }\end{array}$ & $\begin{array}{l}\text { Ambient air in urban ( } 30 \text { drivers) } \\
\text { vs. rural/suburban ( } 27 \text { drivers) } \\
\text { areas }\end{array}$ & $\begin{array}{l}\text { Significantly higher 8-OHdG } \\
\text { excretion in urban drivers vs. } \\
\text { rural/suburban drivers }\end{array}$ & $\begin{array}{l}\text { Very good: exposure is based } \\
\text { upon comparison of urban } \\
\text { (heavily trafficked) vs. rural/ } \\
\text { suburban areas }\end{array}$ \\
\hline Sauvain et al., 2011 [78] & 8-OHdG & $\begin{array}{l}32 \text { Swiss bus } \\
\text { maintenance workers }\end{array}$ & $\begin{array}{l}\mathrm{PM}_{4}, \mathrm{OC}, \mathrm{EC}, \mathrm{PM} \text { metal }(\mathrm{Fe}, \\
\mathrm{Mn}, \mathrm{Cu}) \text { content, } \mathrm{PAHs} \\
\left(\mathrm{PM}_{4} \text { between } 25 \text { and }\right. \\
\left.71 \mu \mathrm{g} / \mathrm{m}^{3}\right)\end{array}$ & $\begin{array}{l}\text { 8-OHdG excretions significantly increased } \\
\text { within each shift and between two } \\
\text { consecutive work days; increases in non- } \\
\text { smokers associated with increases in OC } \\
\text { and particulate } \mathrm{Cu}\end{array}$ & $\begin{array}{l}\text { Very good: associations based } \\
\text { upon exposure measured } \\
\text { indoors, as nearby as possible } \\
\text { to work stations }\end{array}$ \\
\hline Wei et al., 2009 [79] & 8-OHdG & $\begin{array}{l}2 \text { non-smoking young } \\
\text { security guards working } \\
\text { by a major road in Beijing, } \\
\text { noon to } 8 \text { PM; worksite } \\
\text { ambient } \mathrm{PM}_{2.5}=243 \mu \mathrm{g} / \mathrm{m}^{3}, \\
\text { background } \mathrm{PM}_{2.5}=104 \mu \mathrm{g} / \mathrm{m}^{3}\end{array}$ & $\begin{array}{l}\text { Pre and post-shift 8-OHdG } \\
\text { samples collected for } \\
29 \text { days; associations with } \\
\text { four "clusters" of PM } \text { PM.5 }_{2.5} \text { species } \\
\text { (PM } \text { PM.5 }_{2.5} \text { mass, PAHs, metals, polar } \\
\text { organic species) }\end{array}$ & $\begin{array}{l}\text { Post work shift increases in } \\
8-\mathrm{OHdG} \text { significantly associated } \\
\text { with PM } 2.5 \text { mass, PAHs, and metals, } \\
\text { but not with polar organic species, } \\
\text { as measured at worksite }\end{array}$ & $\begin{array}{l}\text { Very good exposure : taken } \\
\text { at worksite }\end{array}$ \\
\hline Lee et al., 2011 [80] & 8-OHdG & $\begin{array}{l}28 \text { diesel exhaust inspectors in } \\
\text { Taiwan, } 38 \text { age and gender } \\
\text { matched controls office } \\
\text { workers, monitored during } \\
3 \text { consecutive day work periods }\end{array}$ & $\begin{array}{l}\text { Diesel } \mathrm{PM}_{2.5} \text { emissions }\left(\mathrm{DEP}_{2.5}\right) \text {, } \\
\text { PAH content of } \mathrm{DEP}_{2.5} \text { (personal } \\
\text { daily } \mathrm{PM}_{2.5}=86 \text { to } 94 \mu \mathrm{\mu g} / \mathrm{m}^{3} \text {, } \\
\text { PAHs }=3.04 \text { to } 4.11 \mathrm{ng} / \mathrm{m}^{3} \text { ) }\end{array}$ & $\begin{array}{l}\text { 8-OHdG levels significantly higher for } \\
\text { inspectors vs. controls on days } 2 \text { and } 3 \text {; } \\
\text { increased PAH concentrations in } \mathrm{DEP}_{2.5} \\
\text { significantly associated with increased } \\
\text { 8-OHdG in exposed group, after } \\
\text { adjusting for smoking status and BMI }\end{array}$ & $\begin{array}{l}\text { Very good: personal monitors } \\
\text { and ambient samplers } \\
\text { installed within meters of } \\
\text { work sites }\end{array}$ \\
\hline Lai et al., 2004 [81] & 8-OHdG & $\begin{array}{l}47 \text { female highway toll } \\
\text { workers in Taiwan, } \\
27 \text { female office workers } \\
\text { as controls }\end{array}$ & $\begin{array}{l}\text { Exposed (toll workers, } 8 \text { hour } \\
\text { shifts) vs. office workers }\end{array}$ & $\begin{array}{l}\text { Toll workers had significantly higher } \\
8-O H d G \text { levels than controls ( } 86 \% \text { higher } \\
8-O H d G \text { comparing non-smokers to non- } \\
\text { smokers); increases in } 8-O H d G \text { almost } \\
5 \text { times higher per } 1000 \text { trucks/buses } \\
\text { than per } 1,000 \text { cars, result not significant } \\
\text { (separate lanes for different vehicle } \\
\text { types) }\end{array}$ & $\begin{array}{l}\text { Very good: exposure defined } \\
\text { by whether working in traffic } \\
\text { or not; for those working in } \\
\text { traffic, further defined by car } \\
\text { lane or truck/bus lane workers } \\
\text { and by traffic density }\end{array}$ \\
\hline
\end{tabular}


Table 1 Human panel studies with good subject exposure methodologies associating measures of oxidative stress with different pm ${ }_{2.5}$ species or specific sources (Continued)

\begin{tabular}{|c|c|c|c|c|c|}
\hline Sorensen et al., 2005 [82] & 8-oxodG & $\begin{array}{l}49 \text { non-smoking students in } \\
\text { Copenhagen, median age } 24, \\
\text { in each of two seasons } \\
\text { (summer, autumn) }\end{array}$ & $\begin{array}{l}\mathrm{PM}_{2.5} \text {, six metals in } \mathrm{PM}_{2.5} \text { fraction } \\
(\mathrm{V}, \mathrm{Cr}, \mathrm{Pt}, \mathrm{Ni}, \mathrm{Cu}, \mathrm{Fe}) ; \\
\mathrm{PM}_{2.5}=20.7 \mu \mathrm{gg} / \mathrm{m}^{3} \text { (fall), } \\
12.6 \mu \mathrm{g} / \mathrm{m}^{3} \text { (summer) }\end{array}$ & $\begin{array}{l}\text { No associations found with urinary } \\
\text { 8-oxodG; significant positive } \\
\text { associations found for V, Cr with } \\
\text { 8-oxodG in lymphocytes. } 98 \\
\text { samples available for urinary } \\
\text { 8-oxodG, } 52 \text { for lymphocytes }\end{array}$ & $\begin{array}{l}\text { Excellent; weekly personal } \\
\text { monitors concentrations for } \\
\text { each season }\end{array}$ \\
\hline Allen et al., 2009 [83] & $\begin{array}{l}\text { 8-OHdG, } \\
\text { F2-isoprostanes }\end{array}$ & $\begin{array}{l}10 \text { adults, ages } 18-49 \text {, with } \\
\text { metabolic syndrome but no } \\
\text { history of ongoing medical } \\
\text { care for heart disease, } \\
\text { hypertension, asthma, } \\
\text { diabetes, or other chronic } \\
\text { condition }\end{array}$ & $\begin{array}{l}2 \text { hour exposure to either diesel } \\
\left.\text { exhaust ( } 200 \mathrm{PM}_{2.5}\right) \text { from } \\
\text { engine operating at } 75 \% \text { of } \\
\text { rated output, or filtered air }\end{array}$ & $\begin{array}{l}\text { No significant increase in 8-OHdG } \\
\text { or F2-isoprostanes levels after } \\
\text { exposure, in double blind crossover } \\
\text { experiment }\end{array}$ & $\begin{array}{l}\text { Excellent: exposure to diesel } \\
\text { emissions or filtered air } \\
\text { occurred in chamber } \\
\text { designed for purpose }\end{array}$ \\
\hline Jacobs et al., 2011 [84] & Oxidized LDL & $\begin{array}{l}79 \text { non-smoking diabetics, } \\
\text { average age } 56.5 \text { years, in } \\
\text { urban Belgium }\end{array}$ & $\begin{array}{l}\text { Carbon area in airway } \\
\text { macrophages, distance of } \\
\text { residences from major roads }\end{array}$ & $\begin{array}{l}\text { Increase in IQR carbon loading, } \\
\text { decrease in distance from major } \\
\text { roads both associated with increase } \\
\text { in oxidized LDL }\end{array}$ & $\begin{array}{l}\text { Excellent: carbon loading } \\
\text { in personal macrophages } \\
\text { is a precise measure of } \\
\text { particulate carbon, which } \\
\text { in urban area is from traffic, } \\
\text { mainly diesels }\end{array}$ \\
\hline Kipen et al., 2011 [85] & $\begin{array}{l}\text { White blood cell } \\
\text { (WBC), red blood cell } \\
\text { (RBC) proteasome } \\
\text { activity, }\end{array}$ & $\begin{array}{l}38 \text { healthy young subjects in } \\
\text { New Jersey }\end{array}$ & $\begin{array}{l}\text { Diesel exhaust (DE), laboratory- } \\
\text { generated secondary organic } \\
\text { aerosol (SOA, based upon gas } \\
\text { phase reactions of ozone and } \\
\text { d-limonene), both } \sim 190 \mu \mathrm{g} / \mathrm{m}^{3}\end{array}$ & $\begin{array}{l}\text { Compared to filtered air exposure, } \\
\text { significant decreases of WBC } \\
\text { proteasome activity after exposure } \\
\text { to either DE or SOA, decrease of } \\
\text { RBC proteasome activity after exposure } \\
\text { to DE, "presumably via induction of } \\
\text { oxidative stress" }\end{array}$ & $\begin{array}{l}\text { Excellent: exposure } \\
\text { chamber used }\end{array}$ \\
\hline Adar et al., 2007 [86] & $\begin{array}{l}\text { HRV measures: SDNN, } \\
\text { r-MSSD, PNN50+1, } \\
\text { LF, HF, LF/HF, HR }\end{array}$ & $\begin{array}{l}44 \text { non-smoking subjects } \\
\text { over age } 60 \text { living in } \\
4 \text { seniors' residences } \\
\text { in St. Louis }\end{array}$ & $\begin{array}{l}\mathrm{BC}, \mathrm{PM}_{2.5} \text { levels as recorded } \\
\text { by mobile monitor which } \\
\text { followed subjects, including } \\
\text { in traffic on bus }\end{array}$ & $\begin{array}{l}\text { For } 24 \text { average } B C \text { concentrations, } \\
\text { for } 5 \text { minute concentrations on } \\
\text { diesel bus or not on bus, and for } 5 \\
\text { and } 24 \text { hour means, the great majority } \\
\text { of many BC associations are significant; } \\
\mathrm{PM}_{2.5} \text { highly correlated with BC and } \\
\text { associations similar to those for BC }\end{array}$ & $\begin{array}{l}\text { Very good (monitor follows } \\
\text { subjects during day, stays } \\
\text { in residence of subjects at } \\
\text { night) }\end{array}$ \\
\hline \multirow[t]{3}{*}{ Schwartz et al., 2005 [87] } & 4 measures of HRV & $\begin{array}{l}27 \text { subjects living adjacent } \\
\text { to major urban road in } \\
\text { Boston, age } 61-89\end{array}$ & $\begin{array}{l}\mathrm{BC}, \mathrm{PM}_{2.5} \text { " "secondary } \mathrm{PM}^{\prime} \\
\text { derived by subtracting } \mathrm{BC} \\
\text { mass from } \mathrm{PM}_{2.5} \text { mass }\end{array}$ & BC: 7 of 8 associations significant & $\begin{array}{l}\text { Very good (monitor adjacent } \\
\text { to same major urban road } \\
\text { to which subjects' residences } \\
\text { also adjacent) }\end{array}$ \\
\hline & & & & $\mathrm{PM}_{2.5}: 3$ of 8 associations significant & \\
\hline & & & & $\begin{array}{l}\text { "Secondary PM": no significant } \\
\text { associations of } 8\end{array}$ & \\
\hline Ebelt et al., 2005 [88] & $\begin{array}{l}\text { SDNN, R-MSSD } \\
\text { measures of HRV }\end{array}$ & $\begin{array}{l}16 \text { non-smoking patients } \\
\text { with COPD in Vancouver, } \\
\text { average age }=74\end{array}$ & $\begin{array}{l}\mathrm{PM}_{2.5} \text {, sulfate, estimated } \\
\text { non-sulfate } \mathrm{PM}_{2.5}\end{array}$ & $\begin{array}{l}\text { Significant associations only with } \\
\text { non-sulfate } \mathrm{PM}_{2.5}\end{array}$ & $\begin{array}{l}\text { Very good (personal } \\
\text { monitoring information } \\
\text { combined with ambient } \\
\text { monitoring information, to } \\
\text { separate effects) }\end{array}$ \\
\hline
\end{tabular}
phase reactions of ozone and (RBC) proteasome activity,

HRV measures: SDNN, 44 non-smoking subjects T-MSSD, PNN50+1, $\quad$ over age 60 living in in St. Louis

27 subjects living adjacent to major urban road in Boston, age 61-89

n-smoking patients with COPD in Vance 
Table 1 Human panel studies with good subject exposure methodologies associating measures of oxidative stress with different pm ${ }_{2.5}$ species or specific sources (Continued)

\begin{tabular}{|c|c|c|c|c|c|}
\hline Creason et al., 2001 [89] & $\begin{array}{l}\text { HF, LF measures } \\
\text { of HRV }\end{array}$ & $\begin{array}{l}56 \text { elderly, non-smoking men, } \\
\text { residents of a retirement } \\
\text { center near Baltimore, } \\
\text { near commuter roads }\end{array}$ & $\begin{array}{l}\mathrm{PM}_{2.5} \text { (sulfate monitored but } \\
\text { not used in models; expressed } \\
\text { as percentage of } \mathrm{PM}_{2.5} \text { in } \\
\text { discussion) }\end{array}$ & $\begin{array}{l}\text { For complete dataset of } 24 \text { days, } \\
\text { insignificant associations with either } \\
\text { HF or LF, with a " } U \text { " shaped function } \\
\text { where HRV measures are at normal } \\
\text { levels only at lowest and highest } \mathrm{PM}_{2.5} \\
\text { concentrations; when a two day period } \\
\text { with no effects on HRV is removed, } \\
\text { remaining } 22 \text { days have a significant, } \\
\text { linear reduction in both HF and LF, } \\
\text { for both indoor and outdoor PM } \\
\text { two days removed had highest and } \\
3^{\text {rd }} \text { highest } \mathrm{PM}_{2.5} \text { levels, were high in } \\
\text { sulfate but came from rural areas with } \\
\text { no apparent urban or industrial source } \\
\text { of harmful } \mathrm{PM}_{2.5}\end{array}$ & $\begin{array}{l}\text { Reasonably good in that } \\
\text { study was able to determine } \\
\text { by wind back-trajectory } \\
\text { analysis that for } 22 \text { days } \\
\text { where } \mathrm{PM}_{2.5} \text { reduced HRV } \\
\text { measures, air parcels passed } \\
\text { over either urban or industrial } \\
\text { areas, but that for the } 2 \text { days } \\
\text { without effect on HRV, parcels } \\
\text { passed over more rural areas }\end{array}$ \\
\hline $\begin{array}{l}\text { Suh and Zanobetti, } \\
2010 \text { [72] }\end{array}$ & $\begin{array}{l}4 \text { measures of HRV: } \\
\text { SDNN, RMSSD, } \\
\text { PNN50, HF, LF/HF }\end{array}$ & $\begin{array}{l}\text { Same as in Wheeler } \\
\text { et al. (2006) }\end{array}$ & EC, sulfate, $\mathrm{PM}_{2.5}$ & $\begin{array}{l}\text { IQR increase in personal monitored } \\
\text { EC significantly associated with } \\
\text { decreases in SDNN, RMSSD, PNN50, } \\
\text { and HF, and with increase in LF/HF; } \\
\text { IQR increase in ambient monitored EC } \\
\text { not associated with changes in any } \\
\text { HRV measures; Neither sulfate nor PM }{ }_{2.5} \\
\text { (only personal monitored available for } \\
\text { sulfate) significantly associated with any } \\
\text { HRV measures }\end{array}$ & $\begin{array}{l}\text { Excellent for personal } \\
\text { monitored EC, } \mathrm{PM}_{2.5} \text { and } \\
\text { sulfate;Poor (horizontal } \\
\text { exposure misclassification; } \\
\text { central monitor reading for } \\
\text { people across metro Atlanta } \\
\text { area) for ambient EC }\end{array}$ \\
\hline \multirow[t]{4}{*}{ Park et al. (2007) [90] } & \multirow[t]{4}{*}{ SDNN, HF, LF, LF/HF } & \multirow[t]{4}{*}{$\begin{array}{l}497 \text { subjects of Normative } \\
\text { Aging Study living across } \\
\text { greater Boston area }\end{array}$} & \multirow[t]{4}{*}{$\begin{array}{l}\mathrm{BC} \text {, sulfate, } \mathrm{PM}_{2.5} \text {, combined } \\
\text { with wind trajectory } \\
\text { information showing source } \\
\text { directions }\end{array}$} & $\begin{array}{l}\text { Four of six trajectories had high and } \\
\text { nearly equal concentrations of } \mathrm{BC} \text {, } \\
\text { sulfate, and } \mathrm{PM}_{2.5} \text { - associations are } \\
\text { for these four trajectories. }\end{array}$ & \multirow[t]{4}{*}{$\begin{array}{l}\text { Poor for BC (horizontal } \\
\text { exposure misclassification; } \\
\text { central monitor reading for } \\
\text { people across metro Boston } \\
\text { area); however, use of wind } \\
\text { trajectory analysis mitigates } \\
\text { poor exposure by allowing } \\
\text { interpretation of rural vs. urban } \\
\text { sources }\end{array}$} \\
\hline & & & & $\begin{array}{l}\text { For local (stagnant) wind trajectory: } \\
\text { BC ( } 2 \text { significant tests of } 4 \text { ); Sulfate } \\
\text { (1 of } 4) ; \mathrm{PM}_{2.5}(1 \text { of } 4)\end{array}$ & \\
\hline & & & & $\begin{array}{l}\text { For long distance urban wind } \\
\text { trajectory from southwest (over } \\
\text { major urban areas): BC ( } 3 \text { of } 4 \text { tests } \\
\text { significant); }\end{array}$ & \\
\hline & & & & $\begin{array}{l}\text { For two non-urban trajectories: } \\
\mathrm{BC} \text {, sulfate, } \mathrm{PM}_{2.5} \text { (none } \\
\text { significant) }\end{array}$ & \\
\hline
\end{tabular}


Table 1 Human panel studies with good subject exposure methodologies associating measures of oxidative stress with different pm ${ }_{2.5}$ species or specific sources (Continued)

\begin{tabular}{|c|c|c|c|c|c|}
\hline Langrish et al., 2009 [91] & SDNN, LF & $\begin{array}{l}15 \text { healthy, non-smoking } \\
\text { young volunteers in } \\
\text { Beijing }\end{array}$ & $\begin{array}{l}\text { Personal monitor } \mathrm{PM}_{2.5} \\
\text { randomized cross over study } \\
\text { design: volunteers walked a } \\
\text { predetermined city center } \\
\text { route with or without a } \\
\text { face mask }\end{array}$ & $\begin{array}{l}24 \text { hour SDNN significantly lower when } \\
\text { face mask not used; LF significantly } \\
\text { lower (one test) without mask, } \\
\text { but interpretation not straightforward }\end{array}$ & $\begin{array}{l}\text { Excellent; most important } \\
\text { finding is corroboration that } \\
\text { urban particulate matter, not } \\
\text { gases, drives reduction in } \\
\text { SDNN, suggesting associations } \\
\text { in other studies with BC/EC } \\
\text { indicate direct PM effects, } \\
\text { BC/EC not a proxy for vehicular } \\
\text { gaseous emissions }\end{array}$ \\
\hline Langrish et al., 2012 [92] & HF, RMSSD & $\begin{array}{l}98 \text { patients with coronary } \\
\text { artery disease, average } \\
\text { age } 62\end{array}$ & $\begin{array}{l}\text { Personal monitor } \mathrm{PM}_{2.5} \\
\text { randomized cross over study } \\
\text { design: volunteers walked a } \\
\text { predetermined city center } \\
\text { route with or without a face } \\
\text { mask }\end{array}$ & $\begin{array}{l}\text { HF, RMSSD significantly lower } \\
\text { when face mask not used }\end{array}$ & $\begin{array}{l}\text { Excellent; most important } \\
\text { finding is corroboration that } \\
\text { urban particulate matter, not } \\
\text { gases, drives reduction in } \\
\text { RMSSD, HF, suggesting } \\
\text { associations in other studies } \\
\text { with BC/EC indicate direct PM } \\
\text { effects, BC/EC not a proxy for } \\
\text { vehicular gaseous emissions }\end{array}$ \\
\hline
\end{tabular}

Abbreviations: $\mathrm{GPx}-1=$ glutathione peroxidase- $1 ; \mathrm{Cu}, \mathrm{Zn}-\mathrm{SOD}=$ copper-zinc superoxide dismutase; $\mathrm{CAD}=$ coronary artery disease; $\mathrm{PN}=$ particle number; $\mathrm{EC}=\mathrm{PM} \mathrm{M}_{2.5}$ elemental carbon; $\mathrm{BC}=\mathrm{PM} \mathrm{M}_{2.5}$ black carbon; $\mathrm{OC}=\mathrm{PM} \mathrm{M}_{2.5}$ organic carbon; $\mathrm{SOA}=$ estimated secondary organic carbon; $\mathrm{OC}_{\text {pri }}=$ primary OC; NAS = Normative Aging Study, a cohort of male veterans across greater Boston area, many of whom are present or former smokers, and many of whom are on anti-hypertensive medications or statins; 8-OHdG or 8-oxodG =8-hydroxy-2'-deoxyguanosine, a product of oxidation of the deoxynucleotide pool and a repair product of oxidation of guanine in DNA (mutagenic); IQR = interquartile range; $\mathrm{PAH}=$ polycyclic aromatic hydrocarbon; BMI = body mass index, a generally reliable indicator of body fat; $\mathrm{HRV}=\mathrm{Heart}$ rate variability, of which there are several measures; SDNN = standard deviation of consecutive RR Intervals (an HRV measure); r-MSSD or RMSSD = root-mean square of the difference of successive R-R intervals (an HRV measure); PNN50 + $1=$ number of instances per hou in which two consecutive R-R intervals differ by more than $50 \mathrm{~ms}$ over $24 \mathrm{~h}$ (an HRV measure); $\mathrm{HF}=$ high frequency component of $\mathrm{HRV}$; $L F=$ low frequency component of $\mathrm{HRV}$; LF/HF= ratio of LF to HF; TP=Total power (an HRV measure); $\mathrm{COPD}=$ Chronic Obstructive Pulmonary Disease; $\mathrm{Ml}=$ Myocardial Infarction; IQR = Interquartile Range of pollutant.

${ }^{1}$ Accuracy of subject exposure is considered very good to excellent if assessment of concentration of pollutant and actual subject exposure vary well together with time because measurement is taken in close proximity to subjects. Accuracy is seem as "horizontally poor" if a central monitor is used to characterized subject exposure over a large geographical area, and is additionally "vertically poor" if the monitor is several hundred feet higher than the residences of the subjects. 


\begin{tabular}{|c|c|c|c|c|}
\hline \multirow{2}{*}{$\begin{array}{l}\text { HRV } \\
\text { measure }\end{array}$} & \multicolumn{2}{|c|}{ Ambient (Central monitor) } & \multicolumn{2}{|c|}{ Personal monitor } \\
\hline & Change (\%) & 95\% confidence interval & Change (\%) & 95\% confidence interval \\
\hline SDNN & -1.0 & -3.7 to 1.7 & -4.66 & -7.99 to -1.22 \\
\hline RMSSD & -3.6 & -9.5 to 2.8 & -10.97 & -18.00 to -3.34 \\
\hline PNN50 & -0.34 & -10.55 to 11.04 & -15.16 & -26.33 to -2.29 \\
\hline HF & -2.36 & -11.67 to 7.92 & -13.41 & -23.95 to -1.41 \\
\hline LF/HF ratio & 2.60 & -1.89 to 7.29 & 6.22 & 0.15 to 12.64 \\
\hline
\end{tabular}

Results in boldface indicate statistical significance at the $95 \%$ confidence level.

PM species were examined: $\mathrm{PM}_{2.5}$ mass, PAHs, metals, and polar organic species. Observed post-shift increases in urinary 8-OHdG were associated with increased levels of $\mathrm{PM}_{2.5}$ mass, PAHs, and metals, but not polar organic species, at the work site.

Lee et al. [80] studied 28 diesel exhaust inspectors in Taiwan, age and gender matched with office worker controls, for three consecutive work days. Pollutants examined were total diesel $\mathrm{PM}_{2.5}\left(\mathrm{DEP}_{2.5}\right)$ and PAH content. 8-OHdG levels were significantly higher for inspectors vs. controls on days 2 and 3. Increased PAH concentrations in $\mathrm{DEP}_{2.5}$ were significantly associated with increased 8-OHdG in the exposed group even after adjusting for factors such as smoking.

Lai et al. [81] studied 47 female toll workers in Taiwan, matched with female office workers as controls; pollution concentrations were not measured. Non-smoking toll workers had significantly higher $8-\mathrm{OHdG}$ levels than did non-smoking controls; increases in 8-OHdG were almost 5 times higher per 1000 trucks/buses than per 1,000 cars (comparing car toll lanes with truck/bus lanes), although these results did not reach statistical significance.

Sauvain et al. [78] studied 32 Swiss bus maintenance workers. PM species examined included $\mathrm{PM}_{4}, \mathrm{OC}, \mathrm{EC}$, metals $(\mathrm{Fe}, \mathrm{Mn}, \mathrm{Cu})$, and PAHs. Urinary $8-\mathrm{OHdG}$ concentrations increased within each work shift, and between two consecutive work days. Among non-smokers, increased 8-OHdG concentrations were associated with increased levels of $\mathrm{OC}$ and $\mathrm{Cu}$. While secondary $\mathrm{OC}$ associations were not found using a different measure of oxidative stress (blood levels of $\mathrm{Cu}, \mathrm{Zn}-\mathrm{SOD}$ ) in the Delfino et al. studies [74,75], primary OC was significantly associated with oxidative stress biomarkers, suggesting that the OC associations in Sauvain et al. reflect mainly fresh (i.e., primary) diesel emissions.

Sorensen et al. [82] used personal monitors to determine levels of $\mathrm{PM}_{2.5}$ and six metals $(\mathrm{V}, \mathrm{Cr}, \mathrm{Pt}, \mathrm{Ni}, \mathrm{Cu}$, $\mathrm{Fe}$ ) in $\mathrm{PM}_{2.5}$ fractions to which 49 young, non-smoking students in Copenhagen were exposed. No associations were found with 8-oxodG in urine, but significant positive associations were found for $\mathrm{V}$ and $\mathrm{Cr}$ with 8-oxodG in lymphocytes.
Kim et al. [76] examined association of urinary 8OHdG with six $\mathrm{PM}_{2.5}$ metal species $(\mathrm{V}, \mathrm{Cr}, \mathrm{Mn}, \mathrm{Ni}, \mathrm{Cu}$, $\mathrm{Pb}$ ) among boilermakers repairing oil-fired boilers in the Boston, MA area. Post-work shift levels of 8-OHdG were significantly higher than pre-work shift levels. Increased 8-OHdG was associated with increases in total $\mathrm{PM}_{2.5}$ and $\mathrm{V}, \mathrm{Mn}, \mathrm{Ni}, \mathrm{Pb}$, but not $\mathrm{Cu}$ or $\mathrm{Cr}$. PM levels were considerably higher than ambient; for example, the concentration of $\mathrm{V}$ was $1.23 \mu \mathrm{g} / \mathrm{m}^{3}$, contrasted with contemporary Boston ambient $\mathrm{V}$ levels of 3 to 5 nanograms $/ \mathrm{m}^{3}$. It is interesting that $\mathrm{Cu}$, but not $\mathrm{Mn}$, was associated with oxidative stress in Sauvain et al. [78], whereas opposite associations were observed for each in Kim et al.

Allen et al. [83] studied 10 adults, aged 18-49, with metabolic syndrome but no history of ongoing medical care for heart disease, hypertension, asthma, diabetes, or similar chronic conditions. Subjects were exposed for two hours either to diesel exhaust $\left(200 \mu \mathrm{g} / \mathrm{m}^{3} \mathrm{PM}_{2.5}\right)$ or filtered air. No significant associations were found between urinary 8-OHdG and diesel exhaust exposure. These findings contrast with studies noting increased urinary 8-OHdG with work shift exposure to diesel exhaust in Taiwan [80] and Switzerland [78], or to heavy vehicular traffic in Taiwan [81] and Beijing [79]. The lack of significant findings of oxidative stress in Allen et al. [83] might have to do with shorter exposure times, with differences in makeup of pollution, with differences in levels of activity, i.e., workers presumably were more physically active during exposure than passively exposed subjects in Allen et al., as suggested by the authors, or to other as yet unknown reasons.

Jacobs et al. [84] chose a unique method of assessing pollution exposure, i.e., by measuring the area occupied by carbon in respiratory tract macrophages, in 79 Belgian non-smoking adult diabetics. The authors also examined distance between subject residence and major roads by geocoding. The biomarker measured was oxidized LDL in plasma, a risk factor for atherosclerosis. They found that both increased carbon loading and decreased distance from major roads were significantly associated with higher levels of oxidized LDL. Similarly, using an animal model, namely atherosclerotic apolipoprotein E knockout mice, 
Lund et al. [93] found that acute exposure to a mixture of gasoline and diesel engine emissions resulted in increased vascular and plasma markers of oxidative stress and the expression of proatherogenic factors.

Kipen et al. [85] exposed healthy young subjects in New Jersey either to diesel exhaust or to a laboratorygenerated $\mathrm{PM}_{2.5}$ secondary organic carbon atmosphere $\left(\sim 190 \mu \mathrm{g} / \mathrm{m}^{3}\right.$ each), with filtered air control for each exposure. Each pollutant atmosphere caused an increase in white blood cell proteasome activity, and the diesel exhaust caused an increase in red blood cell proteasome activity as well, which the authors suggested to indicate oxidative stress. The Delfino et al. studies [74,75] in Los Angeles did not find oxidative stress associated with secondary organic carbon, but the laboratory-generated SOA atmosphere of Kipen et al. did result in such an association. The SOA generated in the laboratory used vegetative organic gases, while the ambient SOA in Los Angeles presumably is mostly from vehicular-derived organic gases. Whether differences in chemical composition due to the differences in source or differences in methods of assessment of oxidative stress, or whether the higher concentrations in the laboratory SOA compared to ambient levels can explain the disparate findings between the Kipen et al. and Delfino et al. studies, is not clear.

While all of the studies noted above directly examined markers of oxidative stress, the results, however, cannot be neatly summarized for several reasons:

- Several studies, in particular those involving urban emissions, did not measure $\mathrm{PM}_{2.5}$ species, and only a few measured $\mathrm{PM}_{2.5}$ metals, which have a high potential for inducing oxidative stress [3].

- Studies were done in several countries, with varying levels and likely composition of urban air pollutants.

- Although most of the studies used urinary 8-OHdG as a biomarker of oxidative stress, some studies used other markers, and it isn't clear a priori whether oxidative stress impacts of PM on telomere erosion are equivalent for various markers.

Given these limitations, we offer the following assessment of these studies:

- In studies performed in the U.S., primary vehicular emissions, such as EC/BC and primary OC, were associated with increases in biomarkers of oxidative stress, but secondary organic carbon, presumably mostly of vehicular origin, was not.

- In studies performed in Europe and Asia, oxidative stress measures were associated with greater exposure to ambient emissions from roads or at tolls (vs. office worker controls); for those driving in urban vs. suburban/rural areas or living closer to roads; for those with higher levels of carbon in airway macrophages; or for those with greater exposure to emissions found in work locations involving diesels or buses. While exposure to these different atmospheres dominated by vehicular emissions clearly resulted in oxidative stress, little information was generally provided as to which specific components of such atmospheres may have been involved. Only one study examined specific $\mathrm{PM}_{2.5}$ species, finding associations with $\mathrm{OC}$ and $\mathrm{Cu}$, but not $\mathrm{EC}, \mathrm{Fe}$, or $\mathrm{Mn}$ in bus maintenance workers.

- Exposures to atmospheres particularly high in $\mathrm{PM}_{2.5}$ metals (boilermakers) or to ambient levels of specific metals such as $\mathrm{V}$ were associated with oxidative stress. However, only three studies examined metals, and associations were not always with the same metals.

Overall, the studies reviewed in this section suggest that exposure to specific PM sources, namely vehicular, are associated with oxidative stress, but because few of the studies included specific PM species, it isn't possible as yet to determine which species were most likely responsible for the oxidative stress. Studies in the next section, using a different proxy for oxidative stress, namely change in heart rate variability (HRV), may provide more details on the potential for several PM species to be so associated.

\section{Studies providing measures of HRV}

Heart rate variability is a reflection of the autonomic nervous system control of cardiac function. Altered HRV has been noted in patients with hypertension and heart failure, and has been linked to increased CVD mortality [92]. Cascio [94] noted that increased cardiac-related deaths and decreased autonomic control of cardiac function can be modulated, at least in part, by oxidative stress. Furthermore, an apparently causal relationship between oxidative stress and changes in various measures of HRV has been found with exposure to pollutants in a number of studies, as discussed below.

Schwartz et al. [95] found significant decreases in the HF component of HRV in people having a deletion for the protein GSTM1, part of the cellular defense against oxidative stress, after exposure to PM. For those that did not have the deletion, however, there were no changes in the HF component. Use of statins protected those with this genetic deficiency against oxidative stress associated with exposure to air pollution. Chahine et al. [96] also found that only those people lacking genes protective against oxidative stress, including a different genetic variant than examined by Schwartz et al. [95], experienced 
reductions in two measures of HRV after PM exposure compared to normal controls. They concluded that oxidative stress was an important pathway for the effects of particles on autonomic nervous function. This is supported by an animal study [97], in which a significant increase in the SDNN component of HRV, which reflects beat-to-beat intervals, and a significant decrease in the ratio of high frequency (HF) to low frequency (LF) components 30 minutes after exposure to urban air particles by instillation was associated with increased oxidative stress in hearts of rats; however, SDNN remained at normal levels when increased oxidative stress was prevented by administration of anti-oxidants prior to exposure (LF/ HF was not analyzed in this regard). Finally, ProbstHensch et al. [98] found that individuals deficient in "oxidant-scavenging" glutathione $S$-transferase (GST) genes had significant HRV alterations, compared to those not so deficient.

Taken together, these studies indicate that changes (mainly reductions) in HRV after exposure to pollutants can reflect induced oxidative stress. Brook et al. [2] noted that "... pathways that reduced endogenous oxidative stress have a protective effect that mitigates reductions in HRV due to ambient PM exposure." Overall, these studies suggest that associations between oxidative stress and changes in measures of HRV are causative, and that such HRV changes can be considered to be markers of oxidative stress induced by pollutant exposure, in this sense parallel to increases in 8-OHdG found in studies discussed in previous sections. This section reviews studies of HRV changes in people for whom exposure to pollutants, such as $\mathrm{BC}$, was reasonably well characterized, for instance, with use of personal monitors, with ambient monitors which traveled with subjects, with monitors in close proximity to a road to which nearby subject residences were also in close proximity, or by use of wind back- trajectory analysis.

Suh and Zanobetti [72] used both personal monitors and a central pollution monitor to assess exposure to $\mathrm{BC}$, sulfate, and $\mathrm{PM}_{2.5}$ in the Atlanta area. The authors found no significant associations with five different measures of HRV when central monitor readings were used. However, risk estimates were 3 to 45 times higher, and $\mathrm{BC}$ was significantly associated with changes in all five measures of HRV (Table 2), when personal monitors were used. Thus, for a pollutant such as $\mathrm{BC}$, having large spatial variability across a metropolitan area, use of central monitor readings failed to accurately characterize differences in exposure to $\mathrm{BC}$ and understated the extent and significance of HRV changes and, thus, of related oxidative stress, relative to more accurate exposure estimates for BC. No HRV associations were noted for either sulfate (only personal monitor data available) or total $\mathrm{PM}_{2.5}$.
Adar et al. [86] used a mobile monitor which followed elderly non-smoking retirees during their activities. Both $\mathrm{BC}$ and $\mathrm{PM}_{2.5}$ concentrations were sharply higher when subjects were on buses than at other times. HRV changes (5 min and $24 \mathrm{~h}$ means) were essentially monotonic with changes in $\mathrm{BC}$ and $\mathrm{PM}_{2.5}$ concentrations, and were significant in the great majority of cases for both pollutants.

Schwartz et al. [87] examined four different measures of HRV for 1 and $24 \mathrm{~h}$ periods. Subjects lived in apartments adjacent to a major Boston roadway; the monitor was also in close proximity to the roadway. BC was consistently associated with changes in all four HRV measures evaluated, while $\mathrm{PM}_{2.5}$ was only occasionally associated. The authors then used an algorithm to remove $\mathrm{BC}$ from $\mathrm{PM}_{2.5}$ each hour, and termed the remainder "secondary PM," which contained regional sulfate and SOC but not BC. They found no associations with HRV changes and secondary PM. Furthermore, SDNN declined monotonically with increasing $\mathrm{PM}_{2.5}$ from the lowest $\mathrm{PM}_{2.5}$ level to about $18 \mu \mathrm{g} / \mathrm{m}^{3}$. At these relatively low levels, the investigators noted that $\mathrm{PM}_{2.5}$ and $\mathrm{BC}$ were highly correlated. However, from about $20 \mu \mathrm{g} / \mathrm{m}^{3}$ to the highest $\mathrm{PM}_{2.5}$ levels (about $50 \mu \mathrm{g} / \mathrm{m}^{3}$ ), the relationship between SDNN and $\mathrm{PM}_{2.5}$ was flat, i.e., there were no changes in the SDNN measure of HRV. At these higher $\mathrm{PM}_{2.5}$ concentrations, $\mathrm{PM}_{2.5}$ was no longer well correlated with $\mathrm{BC}$.

Ebelt et al. [88] examined HRV changes in 16 nonsmoking patients with COPD in Vancouver, Canada. Both ambient and personal monitoring were used to obtain measures of $\mathrm{PM}_{2.5}$; personal monitoring of sulfate was also performed. Non-sulfate $\mathrm{PM}_{2.5}$ was determined by various algorithms which effectively subtracted personal sulfate exposure from $\mathrm{PM}_{2.5}$ measures. Of the different measures of $\mathrm{PM}_{2.5}$, only non-sulfate urban $\mathrm{PM}_{2.5}$ was associated with changes in HRV (SDNN, R-MSSD). These results are the obverse of those of Schwartz et al. [87], in that Ebelt et al. subtracted sulfur to determine urban non-sulfate, which would include BC. However, in both studies, ambient PM reflecting BC or urban air, but not sulfate or regional air, was associated with altered HRV.

Creason et al. [89] examined the relationship between the HF and LF measures of HRV with $\mathrm{PM}_{2.5}$ concentrations over 24 consecutive days in 56 elderly, nonsmoking men. Sulfate was measured, and reported to average $14 \%$ of $\mathrm{PM}_{2.5}$ concentrations, but was not reported separately from $\mathrm{PM}_{2.5}$. The authors found a " $U$ " shaped relationship between changes in HRV measures and $\mathrm{PM}_{2.5}$; HRV changes were most pronounced near the midpoint of $\mathrm{PM}_{2.5}$ concentrations, and HRV was most normal at the lowest and highest $\mathrm{PM}_{2.5}$ concentrations. When a two day air mass, containing the highest and $3^{\text {rd }}$ highest $\mathrm{PM}_{2.5}$ concentrations was removed from the analysis, for the remaining 22 days a monotonic 
reduction in $\mathrm{HF}$ was observed with increasing $\mathrm{PM}_{2.5}$, similar to the reduction in SDNN observed with increasing $\mathrm{BC}$ by both Adar et al. [86] and Schwartz et al. [87]. The authors used back-trajectory analysis to show that the two day air mass, having $\mathrm{PM}_{2.5}$ concentrations of approximately 53 and $37 \mu \mathrm{g} / \mathrm{m}^{3}$, came from rural Pennsylvania, whereas on the other 22 days, the authors suggested that urban or industrial $\mathrm{PM}_{2.5}$ sources were present. The lack of association with $\mathrm{PM}_{2.5}$ on days dominated by rural air masses parallels the findings of Schwartz et al. [87] that $\mathrm{PM}_{2.5}$ in secondary air masses was not associated with changes in HRV, even though $\mathrm{PM}_{2.5}$ levels were highest on such days.

Park et al. [90] studied 497 subjects using back trajectory analysis to create six different source directions to assess exposure. Of primary interest are the four directions which had very similar $\mathrm{BC}, \mathrm{PM}_{2.5}$, and sulfate concentrations (e.g., $\mathrm{PM}_{2.5}$ between 14.1 and $15.1 \mu \mathrm{g} / \mathrm{m}^{3}$; BC between 0.99 and $1.1 \mu \mathrm{g} / \mathrm{m}^{3}$; and sulfate between 3.8 and $4.2 \mu \mathrm{g} / \mathrm{m}^{3}$ ), substantially higher than the remaining two directions ( $\mathrm{N}$ and $\mathrm{NW})$. These four directions were:

- SW (air mass passed over Philadelphia and New York before following the I-95 corridor toward Boston).

- $\mathrm{S}$ (air mass originated in the Carolinas and entered Massachusetts from the ocean to the $\mathrm{S}$ ).

- W (air mass passed over northern Ohio and middle New York state, mostly north of Pennsylvania).

- Local (slow moving air masses, relatively stagnant over Boston).

On days when air masses were less urban ( $\mathrm{S}$ and $\mathrm{W})$, there were no HRV changes associated with any emissions. When air masses arrived in Boston from the SW, $\mathrm{BC}$ was significantly associated with changes in three of four HRV measures; no other $\mathrm{PM}_{2.5}$ species were associated with such changes. When the air was slower moving and more local, $\mathrm{PM}_{2.5}$, sulfate, and $\mathrm{BC}$ were all associated with HRV changes, although BC was associated more consistently.

For two other wind trajectories ( $\mathrm{N}$ and $\mathrm{NW})$, levels of all pollutants were low relative to the other four directions. An association with $\mathrm{PM}_{2.5}$ was observed for the $\mathrm{N}$ wind trajectory, and one for sulfate was seen for the NW wind trajectory. The authors suggested that the effect apparently seen for sulfate in this case, despite low sulfate levels, may actually be due to the presence of transition metals. Lippmann et al. [99] found significant reductions in HRV in mice exposed to ambient air in upstate New York only when the wind trajectory was from the NW, passing over a Sudbury, Ontario nickel smelter.

Two studies that did not monitor $\mathrm{PM}_{2.5}$ species are included in this section because they demonstrate that
HRV changes can be abolished using a face mask that filtered out urban particles, suggesting that the cause of HRV reductions may be traffic-related PM as opposed to associated gaseous vehicular emissions. Langrish et al. [91] recruited 15 young, non-smokers in Beijing for a cross-over study. Subjects walked a predetermined course on separate occasions, either with or without a face mask. Personal $\mathrm{PM}_{2.5}$ monitors were used. A significant decrease in 24-h SDNN was observed when subjects did not use face masks, suggesting production of oxidative stress. Significant reductions in LF were also observed, but interpretation of this effect wasn't straightforward, since LF reflects tone of the sympathetic nervous system and it might have been affected to some extent by simply wearing a mask. Beijing $\mathrm{PM}_{2.5}$ levels when face masks were used were $140 \mu \mathrm{g} / \mathrm{m}^{3}$ vs. $86 \mu \mathrm{g} / \mathrm{m}^{3}$ when masks were not used. In another study, Langrish et al. [92] made similar findings, using subjects with coronary artery disease (average age 62). In addition, they also studied other CVD endpoints, such as ST-segment depression and arterial blood pressure, and found that use of the face mask reduced both. Using electron paramagnetic resonance, the authors also established that ambient PM in Beijing has very high oxidative stress potential.

The results of the studies reviewed in this section may be summarized as follows:

- When there were reasonably accurate subject exposure measures, $\mathrm{BC}$ was consistently significantly associated with alterations in various measures of HRV. Among these studies, those able to distinguish $\mathrm{BC}$ from secondary air masses without $\mathrm{BC}$, rural air masses from those with industrial or urban pollution, urban PM without sulfate vs. those containing sulfate, or personally monitored $\mathrm{BC}$ from personally monitored sulfate, HRV measures were influenced by $\mathrm{BC}$ or urban or industrial air, but not sulfate, regional air masses containing low levels of $\mathrm{BC}$, or rural air masses, even though high in total $\mathrm{PM}_{2.5}$. In these studies, $\mathrm{PM}_{2.5}$ was consistently associated with HRV changes when it was highly correlated with $\mathrm{BC}$, but less so otherwise.

- Although metals were not monitored in any of the HRV studies, the sulfate finding in Park et al. [90] for the air mass with low PM and low sulfate which passed near the Sudbury nickel smelter is suggestive of the Ni association found by Lippmann et al. [99], i.e., HRV was altered in a mouse model only when the wind trajectory was such that the air mass passed near the nickel smelter.

- Those pollutants that were associated with alteration in HRV were also associated with production of oxidative stress which, as noted, can mediate HRV changes. 


\section{Conclusions}

The development of CVD is due to both genetic and environmental factors. However, at an individual level, both susceptibility to and the chronological age at onset of CVD varies between subjects who may have similar classical risk factors. A portion of this interindividual difference likely reflects differences in biological aging. Furthermore, there is evidence that oxidative stress may be a pathogenetic mechanism/risk factor that underlies both such aging and the development of CVD, since oxidative stress has been shown to be related to the initiation and progression of CVD.

Shortened telomere length is a marker of biological age and a key process related to development of agerelated pathology. Telomere shortening itself appears to be a cause of increased rates of morbidity and mortality, both directly as tissue function normally gradually declines, and indirectly as accumulation of senescent cells accelerate development of pathologies.

Studies discussed in this paper have shown that oxidative stress accelerates telomere erosion, and that strategies to reduce oxidative stress can help maintain telomere length. Furthermore, biological aging appears to be related to the cumulative burden of oxidative stress. Telomeric length seems to be related to the development of CVD in certain population groups, oxidative stress appears to be a consistent risk factor for development of CVD, and mean telomere length can act not only as a marker of this process, but a cause.

Vehicular emissions in various settings have been associated with development of oxidative stress. Based upon a small number of investigations examining metals in $\mathrm{PM}_{2.5}$, such species as $\mathrm{Ni}, \mathrm{V}, \mathrm{Cu}, \mathrm{Zn}, \mathrm{Mn}$, and $\mathrm{Cr}$ have all been linked to some measure of oxidative stress. Studies reviewed herein also found that $\mathrm{BC}$ and primary organic carbon is strongly, and consistently, associated with various measures of oxidative stress when there was accurate subject exposure. Secondary air masses, rural air masses or sulfate when examined in HRV studies with accurate exposure assessment were not associated with oxidative stress in these studies.

Since certain components of air pollution or specific types of pollution have been found to result in oxidative stress, it is conceivable that this mechanism underlies an array of diseases associated with increasing age, in particular CVD, the leading cause of death in the U.S. In this review, we have proposed that oxidative stress caused by exposure to certain air pollutants may be responsible for increased mortality and morbidity and for accelerating a host of CVD states or risk factors, by means of accelerating the erosion of telomere length. If this hypothesis is true, then it is possible that air pollutants which cause oxidative stress might be responsible for the majority of air pollution-related CVD mortality and morbidity.
In sum, there is substantial evidence to believe that vehicular emissions, and specific components of such emissions, shorten lives by accelerating the erosion of telomeres via oxidative stress, thus advancing various cardiovascular diseases. This may constitute a generalized pathway by which oxidative stress may induce much of the morbidity/mortality due to vehicular emissions, as hypothesized by the Health Effects Institute [4], although any role of oxidative stress in telomere erosion was not mentioned in that Report. This proposed pathway may also explain the finding that reduction of a unit of ambient $\mathrm{BC}$ was found to extend life 4 to 9 times more than reducing a comparable amount of total $\mathrm{PM}_{2.5}$ [100]. More analysis is needed to understand the extent to which other $\mathrm{PM}_{2.5}$ species may be involved, and also to understand which measures of oxidative stress can most reliably predict accelerated telomere erosion.

\section{Uncertainties and research recommendations}

There are a number of questions and uncertainties that remain to be addressed in relation to the hypothesis proposed in this paper.

- Various biomarkers are often used to reflect environmental pollutant exposures and/or as a surrogate measure of a disease process [101,102]. In order to be useful in this regard, the marker must have some predictive validity, but this is often not the case in that while some markers may be generally indicative of oxidative stress, they may have little relationship to disease processes or outcomes [101,103]. Part of the problem may lie with artifacts produced during the sample collection to sample analysis progression, or due to interaction with factors not being assessed [101]. Furthermore, it is not always clear whether specific markers are reflective of acute or chronic exposure to an oxidative stressor. In addition, a biomarker measured in one cell or tissue may not reflect levels and activity in other cells or tissues and, thus, may not be an appropriate surrogate; therefore, these markers cannot be used interchangeably. [104]. While oxidation products of nucleic acids, lipids and proteins may be found in various tissues, our understanding of the relationship between titers in various tissues and disease processes is often unclear [105]. Thus, with regard to the role of oxidative stress in accelerating the rate of telomere shortening, we need to understand if different markers for detecting oxidative stress are essentially equivalent in indicating the extent of such shortening and under what exposure conditions they may or may not be so reflective. In other words, we need a better understanding of which measures of 
oxidative stress are unambiguously associated with accelerated telomere erosion.

- It is interesting to note that cigarette smoke, a known etiological factor for CVD, has been shown to correlate with accelerated shortening of telomeres in some studies but not in others [106]. It has been suggested that since the correlation between telomere length and smoking appears to be small, it is detectable only with large sample sizes and many studies may have been too small to detect any such association $[102,106]$. Furthermore, the literature that relates cigarette smoking to biomarkers of oxidative stress also provides conflicting results, and this may also be due to small or selected samples or utilization of ambiguous markers [104,107]. It is conceivable that some inconsistency with markers of oxidative stress, telomere length and exposure to air pollutants, as noted herein, may be due to these factors as well.

- There needs to be a fuller understanding of which $\mathrm{PM}_{2.5}$ species cause oxidative stress. It is crucial to have more human panel studies with accurate exposure and which include metals among the $\mathrm{PM}_{2.5}$ species examined. Another way to test which $\mathrm{PM}_{2.5}$ species may cause adverse effects is to perform more crossover studies with face masks in different settings, so as to rule out certain PM components of such air masses as causes of oxidative stress. This will help in setting regulatory policy to protect public health if only particles, and not associated gases, continue to be causally related to oxidative stress.

- It would be useful to undertake further studies to confirm (or otherwise) that secondary air masses with little vehicular or industrial emissions do not cause oxidative stress. One way to do such tests would be to examine people in areas dominated by rural air masses enriched with secondary organic carbon and sulfate, but far from diesel sources, roadways and industry. Tests for circulating and urinary biomarkers and HRV changes could be conducted in concert with monitoring that would include metal species, some of which can apparently cause adverse health effects hundreds of miles from their source even when present in trace amounts.

- The exposure issues noted above would apply even more to studies in Asia and Europe, where close proximity to traffic or to operating diesels away from traffic (e.g., in repair shops or inspection stations) was the metric for exposure, with pollutants such as BC often not monitored. In nearroad environments, it will be important to see if components of road dust, often marked by $\mathrm{Si}$, might also cause oxidative stress. Perhaps a three way test could be used: (A) a road with almost no diesels, in a dry area where road dust would accumulate; (B) a road with almost no diesels, in a wetter area having little road dust accumulation, so that particles would mostly be from vehicular emissions but less from road dust; and (C) a road with many diesels. Effects with and without face masks could be compared, at varying distances from each road, in combination with personal pollution monitors. It is possible that face masks might not prevent oxidative stress in every case, and it is possible that oxidative stress may not be present in every case, which would again be useful knowledge for protecting public health.

- In spite of results from animal and in vitro studies, the ineffectiveness of administered antioxidants in reducing CVD morbidity or mortality in some human clinical and intervention trials has led to a questioning of the importance of oxidative stress in disease pathogenesis $[108,109]$. For example, a comprehensive study found that standard over-thecounter antioxidants appear not to have "expected" beneficial effects on reducing CVD mortality and morbidity [110]. The Antioxidant Supplementation in Atherosclerosis Prevention [111], a study in which 520 men and women were randomized to receive either Vit. E, slow release Vit. C, or a combination of the two, found that men, but not women, benefitted from the combination therapy in terms of the extent of progression of carotid intima media thickness. Other anti-oxidants, such as NAC (N-acetyl-cysteine), might be more helpful than standard vitamins, but seem to have received less study. NAC acts as an antioxidant by replenishing levels of glutathione (GSH), a crucial anti-oxidant produced by the body, and has a longer biological half-time in the body than do "over-the-counter" anti-oxidants such as vitamin C. Another study found that oxidative stress induced by pollution in nursing home residents in Mexico City was significantly reduced by dietary supplementation of omega-3 fatty acids [112]. Thus, it may be that the mixed results in reducing CVD with antioxidants may be due partly to the types of anti-oxidants customarily used, and/or in part to the lack of specific and sensistive biomarkers by which to assess oxidative stress phenotypes that underly CVD [108]. If the hypothesis that air pollutants shorten telomeres via oxidative stress is substantiated, then discovering how to reduce oxidative stress via inexpensive interventions becomes a high priority.

\section{Competing interests}

TG and RBS declare no competing interests.

\section{Authors' contribution}

Both authors contributed throughout the report in terms of writing and editing. TG largely contributed discussions of oxidative stress effects of air pollution, RB largely contributed discussions of effects of oxidative stress on 
telomere length and relationship of CVD to telomere length and oxidative stress. All authors read and approved the final manuscript.

\section{Disclaimer}

This article is dedicated to the memory of Richard Wolf. The opinions expressed herein are those of the authors and do not necessarily reflect the opinion or policy of the United States Department of Energy.

\section{Author details}

'United States Department of Energy, 1000 Independence Avenue, SW Washington, DC 20585, USA. ²Department of Biology and Health Sciences, Dyson College of Arts and Sciences Pace University, One Pace Plaza, New York, NY, USA.

Received: 1 March 2012 Accepted: 29 May 2012

Published: 19 June 2012

\section{References}

1. Brook RD, Franklin B, Cascio W, Hong Y, Howard G, Lipsett M, Luepker R, Mittleman M, Samet J, Smith SC, Tager I: Air pollution and Cardiovascular disease: A statement for healthcare professionals from the Expert Panel on Population and Prevention Science of the American Heart Association. Circulation 2004, 109:2655-2671.

2. Brook RD, Rajagopalan S, Pope CA III, Brook JR, Bhatnagar A, Diez-Roux AV, Holguin F, Hong Y, Luepker RV, Mittleman MA, Peters A, Siscovick D, Smith SC Jr, Whitsel L, Kaufman JD: Particulate Matter Air Pollution and Cardiovascular Disease: An Update to the Scientific Statement from the American Heart Association. Circulation 2010, 121:2331-2378.

3. Kelly FJ: Oxidative Stress: Its Role in Air Pollution and Adverse Health Effects. Occup Environ Med 2003, 60:612-616.

4. Health Effects Institute, Special Report 17: Traffic-Related Air Pollution: A Critical Review of the Literature on Emissions, Exposure, and Health Effects. Boston, Massachusetts:; 2010.

5. Grahame TJ, Schlesinger RB: Cardiovascular health and particulate vehicular emissions: a critical evaluation of the evidence. Air Qual Atmos Health 2010, 3:3-27.

6. Delfino RJ, Staimer N, Vaziri ND: Air pollution and circulating biomarkers of oxidative stress Air Qual Atmos Health 2011, 4:37-52.

7. Samani NJ, van der Harst P: Biological aging and cardiovascular disease. Heart 2008, 94:537-539.

8. Von Zglinicki T, Burkle A, Kirkwood TB: Stress, DNA damage and ageing-an integrative approach. Exp Gerontol 2001, 36:1049-1062.

9. Blackburn EH: Telomerase and cancer. Mol Cancer Res 2005, 3:477-482.

10. Babizhayev MA, Savel'yeva EL, Moskvina SN, Yegorov YE: Telomere length is a biomarker of cumulative oxidative stress, biologic age, and an independent predictor of survival and therapeutic treatment requirement associated with smoking behavior. Amer J Therapeutics 2010, doi:10.1097/MJT.obo13e3181cf8ebb.

11. Epel ES, Blackburn EH, Lin J, Dhabhar FS, Adler NE, Morrow JD, Cawthon RM: Accelerated telomere shortening in response to life stress. PNAS 2004, 101:17312-17315.

12. Baker DJ, Wijshake T, Tchkonia T, LeBrasseur NK, Childs BG, Vand De Sluis B, Kirkland JL, Van Deursen JM: Clearance of p16 ${ }^{\text {Ink4a }}$-positive senescent cells delays ageing-associated disorders. Nature 2011, 479:232-236.

13. Shay JW, Bacchetti S: A survey of telomerase activity in human cancer. Eur J Cancer 1997, 33:787-791.

14. Shay JW, Roninson IB: Hallmarks of senescence in carcinogenesis and cancer therapy. Oncogene 2004, 23:2919-2933.

15. Wong LSM, de Boer RA, Samani NJ, van Veldhuisen DJ, van der Harst P: Telomere biology and heart failure. European J of Heart Failure 2008, 10:1049-1056

16. Hrycek E, Wojakowski W: The role of biological age in cardiovascular disease. Europ. J Cardiovascular Med 2011, 1:46-51.

17. McCracken J, Baccarelli A, Hoxha M, Dioni L, Melly S, Coull B, Suh H, Vokonas P, Schwartz J: Annual Ambient Black Carbon Associated with Shorter Telomeres in Elderly Men: Veterans Affairs Normative Aging Study. Environ Health Perspect 2010, 118:1564-1570.

18. Salpea K, Talmud PJ, Cooper JA, Maubaret CG, Stephens JW, Abelak K, Humphries SE: Association of telomere length with type 2 diabetes, oxidative stress and UCP2 gene variation. Atherosclerosis 2010, 209:42-50.
19. Serra V, Grune T, Sitte N, Saretzki G, von Zglinicki T: Telomere length as a marker of oxidative stress in primary human fibroblast cultures. Ann NY Acad Sci 2000, 908:327-330.

20. Houben JMJ, Moonen HJJ, van Schooten FJ, Hageman GJ: Telomere length assessment: biomarker of chronic oxidative stress? Free Radical Bio Med 2008, 44:235-246.

21. Petersen S, Saretzki G, von Zglinicki T: Preferential accumulation of singlestranded regions in telomeres of human fibroblasts. Exper Lung Res 1998, 239:152-160.

22. Haendeler J, Hoffmann J, Diehl JF, et al: Antioxidants Inhibit nuclear export of telomerase reverse transcriptase and delay replicative senescence of endothelial cells. Circ Res 2004, 94:768-775.

23. Oikawa S, Kawanishi S: Site-specific DNA damage at GGG sequence by oxidative stress may accelerate telomere shortening. FEBS Lett 1999, 368:435-365.

24. von Zglinicki T: Oxidative stress shortens telomeres. Trends Biochem Sci 2002, 27:339-344.

25. Richter T, van Zglinicki T: A continuous correlation between oxidative stress and telomere shortening in fibroblasts. Exp Gerontol 2007, 42:1039-1042.

26. Passos JF, Saretzki G, Ahmed S, et al: "Mitochondrial dysfunction accounts for the stochastic heterogenety in telomere-dependent senescence." PLOS Biol 2007, 5:1-10.

27. Itahana K, Zou Y, Itahana Y, et al: Control of the replicative life span of human fibroblasts by p16 and the polycomb protein. Mol Cell Biol 2003, 23:389-401.

28. Serra V, Von Zglinicki T, Lorenz M, Saretzki G: Extracellular superoxide dismutase is a major antoxidant to human fibroblasts and slows telomere shortening. J Biol Chem 2003, 278:6824-6830.

29. Kashino G, Kodama S, Nakayama Ym Suzuki K, Fukase K, Goto M, Watanabe M: Relief of oxidative stress by ascorbic acid delays cellular senescence of normal human and Werner syndrome fibroblast cells. Free Rad Biol Med 2003, 35:438-443.

30. Von Zglinicki T, Saretzki G, Docke W, Lotze C: Mild hypoxia shortens telomeres and inhibits proliferation of fibroblasts: a model for senescence? Exp Lung Res 1995, 220:186-193.

31. Sanders JL, Fitzpatrick AL, Boudreau RM, Arnold AM, Aviv A, Kimura M, Fried LF, Harrris TB, Newman AB: Leukocyte telomere length is associated with noninvasively measured age-related disease: the Cardiovascular Health Study. J. Gerontology Series A: Biological Sciences and Medical Sciences 2011, doi.10.1093/Gerona/grl/173.

32. Fitzpatrick AL, Kronmal RA, Gardner JP, Psaty BM, Jenny NS, Tracy RP, Walston J, Kimura K, Aviv A: Leukocyte telomere length and cardiovascular disease in the cardiovascular health study. Amer $J$ Epidemol 2006, 165:14-21.

33. Houben JM, Giltay Ej, Rius-Ottenheim N, Hagman GJ, Kromhout D: Telomere length and mortality in elderly men: the Zutphen Elderly Study. J. Gerontology: Series A: Biological Sciences and Medical Sciences 2011, 66A:38-44.

34. DeMeyer T, Rietzschel ER, De Buyzere MI, et al: Systemic telomere length and preclinical atherosclerosis: the Asklepios Study. Eur Heart J 2009, 30:3074-3081.

35. O'Donnell CJ, Demissie S, Kimura M, et al: Leukocyte telomere length and carotid artery intimal medial thickness: the Framingham Heart Study. Arteriosclerosis Thromb Vasc Biol 2008, 28:1165-1171.

36. Brouilette SW, Moore JS, McMahon AD, Thompson JR, Ford I, Shepherd J, Packard CJ, Samani NJ: Telomere length, risk of coronary heart disease, and statin treatment in the West of Scotland Primary Prevention Study: a nested case-control study. Lancet 2007, 369:107-114.

37. Cawthon RM, Smith KR, O'Brien E, Sivatchenko A, Kerber RA: Association between telomere length in blood and mortality in people aged 60 years or older. Lancet 2003, 361:393-395.

38. Brouilette S, Singh RK, Thompson JR, Goodall AH, Samani NJ: White Cell telomere length and risk of premature myocardial infarction. Arteriosclerosis. Thromb Vasc Biol 2003, 23:842-6.

39. Chimenti C, Kajstura J, Torella D, et al: Senescence and death of primitive cells and myocytes lead to premature cardiac aging and heart failure. Circ Res 2003, 93:604-13.

40. Urbanek K, Torella D, Sheikh F, De Angelis A, Nurzynska D, Silverstri F, Beltrami CA, Bussani R, Beltram AP, Quaini F, Bolli R, Leri A, Kajustra J, Anversa P: Myocardial regeneration by activation of multipotent 
cardiac stem cells in ischemic heart failure. Proc Natl Acad Sci 2005, 102:8692-8697.

41. Oh H, Wang SC, Prahash A, et al: Telomere attrition and Chk2 activation in human heart failure. Proc Natl Acad Sci 2003, 100:5378-83.

42. Wong LSM, Huzen J, de Boer RA, van Gilst WH, van Veldhuisen DJ, van der Harst P: Telomere length of circulating leukocyte subpopulations and buccal cells in patients with ischemic heart failure and their offspring. PLoS One 2011, 6:23118. jdoi:10.1371.

43. Kuznetsova T, Codd VS, Lutgarde T, Gonzalez A, Jin Y, Richart T, van der Harst P, Diez J, Staessen JA, Samani NJ: Association between left ventricular mass and telomere length in a population study. Am $J$ Epidemiol 2010, 172:440-450.

44. Takubo K, Izumiyama-Shimomura N, Homma N, et al: Telomere lengths are characteristic in each human individual. Exp Gerontol 2002, 37:523-31.

45. Youngren $\mathrm{K}$, Jeanclos $\mathrm{E}$, Aviv $\mathrm{H}$, et al: Synchrony in telomere length of the human fetus. Hum Genet 1998, 102:640-3.

46. Collerton J, Martin-Ruiz C, Kenny A, et al: Telomere length is associated with left ventricular function in the oldest old: the Newcastle $85+$ Study. Eur Heart J 2007, 28:172-6.

47. Kurz DJ, Kloeckener-Gruissem B, Akhmedov A, et al: Degenerative aortic valve stenosis, but not coronary disease, is associated with shorter telomere length in the elderly. Arterioscler Thromb Vasc Biol 2006, 26:e114-7.

48. Chimenti C, Kajstura J, Torella D, Urbanek K, Heleniak H, Colussi C, DiMeglio F, Nadal-Ginard V, Frustaci A, Leri A, Maseri A, Anversa P: Senescence and death of primitive cells and myocytes lead to premature cardiac aging and heart failure. Circ Res 2003, 93:604-613.

49. Leri A, Franco S, Zacheo A, et al: Ablation of telomerase and telomere loss leads to cardiac dilatation and heart failure associated with $\mathrm{p} 53$ upregulation. EMBO J 2003, 22:131-9.

50. Bekaert S, De Meyer T, Rietzschel ER, De Buyzere ML, Langlois M, Segers $P$, Cooman L, van Damme $P$, Cassiman $P$, van Criekinge W, Verdonck P, de Backer GG, Gillebert TC, van Ostveldt P: Telomere length and cardiovascular risk factors in a middle-aged population free of overt cardiovascular disease. Aging Cell 2007, 6:639-647.

51. Olivieri F, Antonicelli R, Recchioni R, Mariotti S, Marcheselli F, Lisa R, Spazzafumo L, Galeazzi R, Caraceni D, Testa R, Latini R, Procopio AD Telomere/telomerase system impairment in circulating angiogenic cells of geriatric patients with heart failure. Inter J Geron 2011, doi:10.1016/j. ijcard.2011.06.091.

52. Crouse JR: Imaging atherosclerosis: state of the art. J Lipid Res 2006, 47:1677-99.

53. Schoepf UJ, Becker CR, Ohnesorge BM, Yucel EK: CT of coronary artery disease. Radiology 2004, 232:18-37.

54. Detrano R, Guerci AD, Carr JJ, et al: Coronary calcium as a predictor of coronary events in four racial or ethnic groups. N Engl J Med 2008 358:1336-45.

55. McClelland RL, Nasir K, Budoff M, Blumenthal RS, Kronmal RA: Arterial age as a function of coronary artery calcium (from the Multi-Ethnic Study of Atherosclerosis (MESA). Am J Cardiol 2009, 103:59-63.

56. Mainous AG III, Codd V, Diaz VA, Schoepf UJ, Everet CH, Player MS, Samani NJ: Leukocyte telomere length and coronary artery calcification. Atherosclerosis 2010, 210:262-267.

57. Benetos A, Gardner JP, Zureik M, et al: Short telomeres are associated with increased carotid atherosclerosis in hypertensive subjects. Hypertension 2004, 43:182-5.

58. Nzietchueng R, Elfarra M, Nloga J, Labat C, Carteaux JP, Maureira P, Lacolley P, Villemot JP, Benetos A: Telomere length in vascular tissues from patients with atherosclerotic disease. J Nutrition Health Aging 2011, 15:153-156.

59. Huzen J, Peeters W, de Boer RA, Moll FL, Wong LSM, Codd V, de Kleijn DPV, de Smet BJGL, van Veldhuisen DJ, Samani NJ, van Gilst WH, Pasterkamp G, van der Harst P: Circulating leukocyte and carotid atherosclerotic plaque telomere length. Arteriosclerosis Thromb Vascular Biology 2011, 31:1219-1225.

60. Mc Ewen B: Protecting and damaging effects of stress mediators. N Eng/ J Med 1998, 338:171-179.

61. Segerstrom S, Miller G: Psychological stress and the human immune system: a meta-analytic study of 30 years of inquiry. Psychol Bull 2004, 130:601-630.

62. Mclntosh LJ, Sapolsky RM: Glucocorticoids may enhance oxygen radicalmediated neurotoxicity. Neurotoxicology 1996, 17:873-882.
63. Patel R, Mclntosh L, Mc Laughlin J, Brooke S, Nimon V, Sapolsky R, Sapolsky R: Disruptive effects of glucocorticoids on glutathione peroxidase biochemistry in hippocampal cultures. J Neurochem 2002, 82:118-125.

64. Wolkowitz OM, Mellon SH, Epel ES, Lin J, Dhabhar FS, Su Y, Reus VI, Rosser R, Burke HM, Kupferman E, Compagnone M, Nelson JC, Blackburn EH: Leukocyte telomere length in major depression: correlations with chronicity, inflammation, and oxidative stress - preliminary findings. PLoS One 2011, 63: e17837. doi:10.1371/journal.pone.0017837.

65. Satoh M, Ishikawa Y, Takahashi Y, Itoh T, Minami Y, Nakamura M: Association between oxidative DNA damage and telomere shortening in circulating endothelial progenitor cells obtained from metabolic syndrome patients with coronary artery disease. Atherosclerosis 2008, 198:347-353.

66. Chen W, Gardner JP, Kimura M: Leukocyte telomere length is associated with HDL cholesterol levels: the Bogalusa study. Atherosclerosis 2009, 205:620-625.

67. Fuster JJ, Andres V: Telomere aging and cardiovascular disease. Circulation Res 2006, 99:1167-1180.

68. Breitschopf K, Zeiher AM, Dimmeler S: Pro-artherogenic factors induce telomerase inactivation in endothelial cells through an Akt-dependent mechanism. FEBS Lett 2001, 493:21-25.

69. Kurz DJ, Decary S, Hong Y, Trivier E, Akhmedov A, Eursalimsky JS: Chronic oxidative stress compromises telomere integrity and accelerates the onset of senescence in human endothelial cells. J Cell Sci 2004, 117:2417-2426.

70. Valdes AM, Andrew T, Gardner JP, et al: Obesity, cigarette smoking and telomere length in women. Lancet 2005, 366:662-664.

71. Hoxha M, Dioni L, Bonzini M, Pesatori AC, Fustinoni S, Cavallo D, Carugno M, Albetti B, Marinelli B, Schwartz J, Bertazzi PA, Baccarelli A: Association between leukocyte telomere shortening and exposure to traffic pollution: a crosssectional study on traffic officers and indoor office workers. Environ Health 2009, 8:41.

72. Suh HH, Zanobetti A: Exposure Error Masks the Relationship Between Traffic-Related Air Pollution and Heart Rate Variability. J Occ Environ Med 2010, 52:685-692.

73. Hsu S-I, Ito K, Lippmann M: Effects of thoracic and fine PM and their components on heart rate and pulmonary function in COPD patients. $J$ Expos Sci Environ Epidemiology 2011, 21:464-472.

74. Delfino RJ, Staimer N, Tjoa T, Polidori A, Arhami M, Gillen DL, Kleinman MT, Vaziri ND, Longhurst J, Zaldivar F, Sioutas C: Circulating biomarkers of inflammation, antioxidant activity, and platelet activation are associated with primary combustion aerosols in subjects with coronary artery disease. Environ Health Perspect 2008, 116:898-906.

75. Delfino RJ, Staimer N, Tjoa T, Gillen DL, Polidori A, Arhami M, Kleinman MT, Vaziri ND, Longhurst J, Sioutas C: Air Pollution Exposures and Circulating Biomarkers of Effect in a Susceptible Population: Clues to Potential Causal Component Mixtures and Mechanisms. Environ Health Perspect 2009, 117:1232-1238.

76. Kim JY, Mukherjee S, Ngo L, Christiani DC: Urinary 8-Hydroxy-2'Deoxyguanosine as a Biomarker of Oxidative DNA Damage in Workers Exposed to Fine Particulates. Environ Health Perspect 2004, 112:666-671.

77. Loft S, Poulsen HE, Vistisen K, Knudsen LE: Increased urinary excretion of 8-oxo-2'-deoxyguanosine, a biomarker of oxidative DNA damage, in urban bus drivers. Mutat Res 1999, 441:11-9.

78. Sauvain J-J, Setyan A, Wild P, Tacchini P, Lagger G, Storti F, Deslarzes S, Guillemin M, Rossi MJ, Riediker M: Biomarkers of oxidative stress and its association with the urinary reducing capacity in bus maintenance workers. J of Occup Med Toxicol 2011, 6:1-13.

79. Wei Y, Han I-K, Shao M, Hu M, Zhang J, Tang X: PM ${ }_{2.5}$ Constituents and Oxidative DNA Damage in Humans. Environ Sci Technol 2009, 43:4757-4762.

80. Lee M-W, Chen M-L, Lung S-CC, Tsai C-J, Lai C-FS, Yang S-C, Mao I-F: Increase of urinary concentrations of 8-hydroxy-20- deoxyguanosine in diesel exhaust emission inspector exposed to polycyclic aromatic hydrocarbons. Int Arch Occup Environ Health 2011, 85(3):273-282.

81. Lai C-H, Liou S-H, Lin H-C, Shih T-S, Tsai P-J, Chen J-S, Yang T, Jaakkola JJK, Strickland PT: Exposure to traffic exhausts and oxidative DNA damage. Occup Environ Med 2005, 62:216-222.

82. Sorensen M, Schins RPF, Hertel O, Loft S: Transition Metals in Personal Samples of $\mathrm{PM}_{2.5}$ and Oxidative Stress in Human Volunteers. Cancer Epidemiol Biomarkers Prev 2005, 14:1340-1343. 
83. Allen J, Trenga CA, Peretz A, Sullivan JH, Carlsten CG, Kaufman JD: Effect of diesel exhaust inhalation on antioxidant and oxidative stress responses in adults with metabolic syndrome. Inhal Toxicol 2009, 21:1061-1067.

84. Jacobs L, Emmerechts J, Hoylaerts MF, Mathieu C, Hoet PH, et al: Traffic Air Pollution and Oxidized LDL. PLOS ONE 2011, 6(1):e16200. doi:10.1371/ journal.pone.0016200. online publication, no page numbers.

85. Kipen HM, Gandhi S, Rich DQ, Ohman-Strickland P, Laumbach R, Fan Z-H, Chen L, Laskin DL, Zhang J, Madura K: Acute Decreases in Proteasome Pathway Activity after Inhalation of Fresh Diesel Exhaust or Secondary Organic Aerosol. Environ Health Perspect 2011, 119:658-663.

86. Adar SD, Gold DR, Coull BA, Schwartz J, Stone PA, Suh H: Focused exposures to airborne traffic particles and heart rate variability in the elderly. Epidemiology 2007, 18:95-103.

87. Schwartz J, Litonjua A, Suh H, Verrier M, Zanobetti A, Syring M, Nearing B, Verrier R, Stone P, MacCallum G, Speizer FE, Gold DE: Traffic related pollution and heart rate variability in a panel of elderly subjects. Thorax 2005, 60:455-461.

88. Ebelt ST, Wilson WE, Brauer M: Exposure to ambient and nonambient components of particulate matter. Epidemiology 2005, 16:396-405.

89. Creason J, Neas L, Walsh D, Williams R, Sheldon L, Liao D, Shy C: Particulate matter and heart rate variability among elderly retirees: the Baltimore 1998 PM study. J Environ Expos Anal Environ Epidemiol 2001, 11:116-122.

90. Park SK, O'Neill MS, Stunder BJB, Vokanas PS, Sparrow D, Koutrakis P, Schwartz J: Source location of air pollution and cardiac autonomic function: Trajectory cluster analysis for exposure assessment. J Expo Sci Environ Epidemiol 2007, 17:488-497.

91. Langrish JP, Mills NL, Chan JK, Leseman DL, Aitken RJ, Fokkens PH, Cassee FR, Li J, Donaldson K, Newby DE, Jiang L: Beneficial cardiovascular effects of reducing exposure to particulate air pollution with a simple facemask. Part Fibre Toxicol 2009, 6:8.

92. Langrish JP, Li X, Wang S, Lee MMY, Barnes GDE, Miller MR, Cassee FR, Boon NA, Donaldson K, Li J, Li L, Mills NL, Newby DE, Jiang L: Reducing Personal Exposure To Particulate Air Pollution Improves Cardiovascular Health In Patients With Coronary Heart Disease. Environ Health Perspect 2012 120:367-372.

93. Lund AK, Lucero J, Harman M, Madden MC, MCDonald JD, Seagrave JC, Campen MJ: The oxidized low-density lipoprotein receptor mediates vascular effects of inhaled vehicle emissions. Am J Respir Crit Care Med 2011, 184:82-91.

94. Cascio W: Cardiopulmonary Health Effects of Air Pollution: Is a Mechanism Emerging? Am J Resp Crit Care Med. 2005, 172:1482-1483.

95. Schwartz J, Park SK, O’Neill MS, Vokonas PS, Sparrow D, Weiss S, Kelsey K: Glutathione-S-Transferase M1, obesity, statins, and autonomic effects of particles. Am M Respir Crit Care Med 2005, 172:1529-1533.

96. Chahine T, Baccerelli A, Litonjua A, Wright RO, Suh H, Gold DR, Sparrow D, Vokonas P, Schwartz J: Particulate air pollution, oxidative stress genes, and heart rate variability in an elderly cohort. Environ Health Perspect 2007, 115:1617-1622.

97. Rhoden CR, Wellenius GA, Ghelfi E, Lawrence J, Gonzalez-Flecha B: PMinduced cardiac oxidative stress and dysfunction are mediated by autonomic stimulation. Biochim Biophys Acta 2005, 172:305-313.

98. Probst-Hensch NM, Imboden M, Dietrich DF, Barthelemy J-C, AckermannLiebrich U, Berger W, Gaspoz J-M, Schwartz J: Glutathione S-Transperase polymorphisms, passive smoking, obesity, and heart rate variability in nonsmokers. Environ Health Perspect 2008, 116:1491-1499.

99. Lippmann M, Ito K, Hwang J-S, Maciejczyk P, Chen LC: Cardiovascular effects of nickel in ambient Air. Environ Health Perspect 2006, 114:1662-1669.

100. Janssen NAH, Hoek G, Simic-Lawson M, Fischer $P$, van Bree $L$, ten Brink $H$, Keuken M, Atkinson RW, Anderson HR, Brunekreef B, Cassee FR: Black Carbon as an Additional Indicator of the Adverse Health Effects of Airborne Particles Compared with PM10 and PM 2.5 . Environ Health Perspect 2011, 119:1691-1699.

101. Blumberg J: Use of biomarkers of oxidative stress in research studies. J. Nutrition 2004, 134:3188S-3189S

102. Mayne ST: Antioxidant nutrients and chronic disease: use of biomarkers of exposure and oxidative stress status in epidemiological research. J Nutr 2003, 133:933S-940S.

103. Schisterman EF, Faraggi D, Browne R, Freudenheim J, Dorn J, Muti $P$ Armstrong D, Reiser B, Trevisan M: Minimal and best linear combination of oxidative stress and antioxidant biomarkers to discriminate cardiovascular disease. Nutr Metab Cardiovasc Dis 2002, 12:259-266.
104. Trevisan M, Browne R, Ram M, Muti P, Freudenheim J, Carosella AM, Amstrong D: Correlates of markers of oxidative status in the general population. Amer J Epidemiol 2001, 154:348-356.

105. Milbury P, Blumberg J: Dietary antioxidants-human studies overview. In Critical Reviews of Oxidative Stress and Aging: Advances in Basic Science, Diagnostics, and Intervention. Edited by Rodriguez H, Cutler RG. River Edge NJ: World Scientific; 2003.

106. Mirabello L, Huang W-Y, Wong JYY, Chatterjee N, Reding D, Crawford ED, DeVivo I, Hayes RB, Savage SA: The association between leukocyte telomere length and cigarette smoking, dietary and physical variables, and risk of prostate cancer. Aging Cell 2009, 8:405-413.

107. Cross CE, van der Vliet A, Eiserich JP: Cigarette smokers ad oxidant stress: a continuing mystery. Amer J Clin Nutr 1998, 67:184-185.

108. Madamanchi NR, Vendrov A, Runge MS: Oxidative stress and vascular disease. Arteriosclerosis, Thrombosis, Vascular Bio 2005, 25:29-3.

109. Jones DP: Redefining oxidative stress. Antioxid Redox Signal 2006, 8:1865-1879

110. U.S. Preventive Services Task Force: Routine Vitamin Supplementation To Prevent Cancer and Cardiovascular Disease: Recommendations and Rationale. Ann Intern Med 2003, 139:51-55.

111. Gotto AM: Antioxidants, Statins, and Atherosclerosis. J Am Coll Cardiol 2003, 41:1205-10.

112. Romieu I, Garcia-Esteban R, Sunyer J, Rios C, Alcaraz-Zubeldia M, Velasco SR, Holguin F: The Effect of Supplementation with Omega-3 Polyunsaturated Fatty Acids on Markers of Oxidative Stress in Elderly Exposed to $\mathrm{PM}_{2.5}$. Environ Health Perspect 2008, 116:1237-1242.

\section{doi:10.1186/1743-8977-9-21}

Cite this article as: Grahame and Schlesinger: Oxidative stress-induced telomeric erosion as a mechanism underlying airborne particulate matter-related cardiovascular disease. Particle and Fibre Toxicology 2012 9:21.

\section{Submit your next manuscript to BioMed Central and take full advantage of:}

- Convenient online submission

- Thorough peer review

- No space constraints or color figure charges

- Immediate publication on acceptance

- Inclusion in PubMed, CAS, Scopus and Google Scholar

- Research which is freely available for redistribution 